\title{
Com Furores de Marte e com Astúcias de Mercúrio: 0 Dell'Arte Historica (1636) de Agostino Mascardi
}

\author{
Eduardo Sinkevisque
}

\section{Furores de Marte}

Em 1636, Agostino Mascardi ${ }^{1}$, filho de um célebre jurisconsulto, Alderan Mascardi, dá à estampa seu tratado Dell'Arte Historica, dedicando-o ao Duque Giovan Francesco Brignole, ao Governador da República de Gênova e à "illustrissima” Accademia de Signori Humoristi de Roma, da qual era, na altura, o "Príncipe", ou o principal entre aqueles acadêmicos.

O Dell'Arte Historica é uma preceptiva retórico-poético-historiográfica do século XVII que teve, ao menos, cinco edições seiscentistas e três reedições nos séculos XIX e XX. Pode ser traduzida como "sobre a arte histórica" ou "da arte histórica" ou, simplesmente, "arte histórica”. Essa preceptiva é, basicamente, uma amplificação de preceitos retóricos, poéticos e historiográficos de Cícero e de Luciano de Samósata, entre outras auctoritates do gênero, sobre o modo seiscentista de se escrever História. Do que se sabe, esse texto nunca foi citado, nem lido, muito menos aplicado em nenhum estudo brasileiro ou português sobre a História ibérica do século XVII; com exceção, talvez, do recente estudo que empreendi em nível de doutoramento ${ }^{2}$. A rigor, a tradução da preceptiva é: Cinco Tratados sobre Arte Histórica ${ }^{3}$.

A academia dos humorados dedicava-se sobretudo à prática das letras e filosofias morais e à pratica de uma poesia sublime, em conformidade com as doutrinas da Igreja Católica pós-tridentina. Lutar contra a heresia, celebrando o florescimento das artes liberais e da filosofia moral, na proteção de uma Igreja consolidada era o principal intuito dos humorados da Roma de então. Esforçavam-se por praticar uma eloqüência didática, efi- 
caz o suficiente para corresponder ao programa teológico-político-retórico de Urbano VIII que combatia seu adversário comum, Giambattista Marino. A rivalidade, no entanto, estabelecia-se de academia para academia (humorados versus adormecidos), de cidade-Estado para cidade-Estado (Gênova versus Roma). A Academia dos Humorados era pública e universitária, enquanto que a dos Adormecidos era privada e citadina de formato republicano. Os humorados polemizavam com os adormecidos, cujo fundador foi Giulio Pallavicino. Em discussão estava o estilo, em particular o estilo agudo, mas principalmente questôes políticas ou de poder. Antigos, como Mascardi, pensavam regular o engenho, a agudeza por meio do juízo, enquanto modernos, como Peregrini, propunham um 'estilo novo' em que o engenho e a agudeza se autonomizassem do juízo.

Marino, também eleito "Príncipe" dos humorados de Roma (1623), foi responsável por uma eloqüência sacra, de aliança teológico-retórica, cujos modelos são menos os Padres que os sofistas, seus mestres e rivais. A "segunda sofística”, a qual Marino atua, caracteriza-se pelo triunfo do gênero epidítico privado da finalidade cívica ou judiciária, mas tendendo ao deleite.

Não é de estranhar que o letrado genovês compusesse o Dell'Arte Historica, não só porque versado nos assuntos e praticante do gênero história, entre outros, mas porque, como "Príncipe dos humorados", conhecia bem o gênero epidítico, do qual o encômio é a variante historiográfica por definição e o vitupério a variante cômico-satírica por excelência.

Não é por acaso também que elegesse Luciano de Samósata e Marco Túlio Cícero ${ }^{4}$ como auctoritates a serem amplificadas, imitadas e emuladas, antes mesmo que o Padre e Conde Emanuele Tesauro editasse o seu Il Cannocchiale Aristotélico (...) $(1654)^{5}$ no qual amplifica, como o próprio título diz, com luneta, os preceitos retórico-poéticos de Aristóteles, principalmente.

Mascardi faz, portanto, uma luneta que, editada anteriormente à de Tesauro, autoriza-se em um filósofo satírico grego, de origem síria, segundo o decoro de sua academia dos humorados e em um orador e retor latino, segundo não só o decoro das academias letradas ibérico-italianas, sobretudo, segundo a querela travada com Manzini contra a tradição marinista, nas discussões sobre sofística, nova sofística etc. As duas lunetas, no entanto, devem ter circulado em forma manuscrita concomitantemente, o que era comum, uma vez que compostas contemporaneamente, como parte da querela com os marinistas. 
A querela Mascardi/Manzini é querela anti os (ou a favor dos) ciceronianos e não anti-Cícero ou a favor de Cícero. Querela sobre os usos de Cícero, portanto, moralizados catolicamente no século XVII. Querela entre os que reciclavam a primeira sofística e os que reciclavam a segunda, sendo guerra para quem dizia não admitir sofística nenhuma, como Mascardi.

Manzini era partidário de um tipo de narrativa maravilhosa, engenhosa e fantástica, da qual se julgava o opus oratorium maxime, ao contrário de Famiano Strada e de Agostino Mascardi. Estes eram propensos a uma eloqüência sagrada, cuja narrativa oratório-historiográfica deveria ser icástica e não fantástica, como acreditavam ser as narrativas fantásticas da nova sofística marinista autorizada em Luciano de Samósata.

"Icástico" significa o modelo de juízo sem fantasia, ou, no máximo, fantasia com juízo; nunca fantasia sem juízo. "Fantástico" é o estilo que opera deformações sem regra aparente do juízo. Icástica, predominantemente, é a imagem proporcional ao paradigma; fantástica é imagem de imagem. Nesse sentido, os partidários de Giambattista Marino eram a favor do engenho, dos modelos fantásticos, enquanto que os partidários de Strada e de Mascardi eram a favor dos modelos icásticos e partidários do juízo. Como destaca Hansen,

(...) Gracián retoma Peregrini, quando escreve que o engenho também é uma faculdade prática relacionada às artes, ou seja, à verossimilhança, pois visa a fabricação do belo e do eficaz, no sentido da ratio cogitandi visque dicendi. A fabricação artística do 'belo eficaz', outro nome do conceito engenhoso, não se ocupa da verdade, como a filosofia, mas da formosura verossímil. Doutrinada tradicionalmente como modalidade incluída na retórica, a formosura continua a ser uma decorrência da dialética, que fornece os meios para formalizar as imagens como silogismos retóricos. Como disse, a finalidade do 'belo eficaz' não é a verdade, mas a verossimilhança das imagens que imitam opinióes tidas por verdadeiras e que se tornam muito distanciadas umas das outras e, ao mesmo tempo, os procedimentos técnicos aplicados para efetuá-las (... $)^{6}$. Logo, segundo outro lugar-comum seiscentista, afirma-se que, nas artes, assim como o juízo sem agudeza é vulgaridade árida, também a fantasia sem juízo é afetação própria de néscios ou vulgares: infarinatti di lettere, como se viu com Peregrini. Decoroso é o meio-termo da proporção racional do juízo, como determina Aristóteles; logo, decorosa é a fantasia maravilhosamente aguda, cuja desproporção 
resulta da proporção de um juízo icástico, prudente ou discreto, que a calcula racionalmente $(\ldots)^{7}$.

Mascardi era contrário à nova sofística marinista-senequista, da qual Tesauro era participante e Manzini, na Academia dos Humorados de Roma, o principal defensor. Agostino Mascardi atuava a favor do "ciceronianismo devoto", do qual o Padre Famiano Strada, em 1617, já havia lançado as bases anti-sofísticas de reafirmação no Ratio Studiorum, exercendo uma espécie de pontificado retórico em Roma.

Suas doutrinas uniam a sagacidade da eloqüência de bases socráticas e ciceronianas, opondo o engenho dos grandes ânimos e das grandes paixões ao juízo dos estilos humilde e médio, tendendo, no máximo, ao alto e grave. $\mathrm{O}$ engenho é rápido, ágil, perspicaz. O juízo é um freio donde se extrai a prudência que faz agir pondo as paixões sob controle.

Agostino Mascardi e o Padre Strada formariam as bases de uma retórica "da justa medida latina contra a sofística sacra ou profana da narração e da declamação" fantásticas. Contrários, portanto, à obscura brevitas de um Justo Lípsio, contrários à "retórica escolar de uma sofística inchada e insincera", cujas forças se propõem como "bastiāo de resistência ao marinismo”. Mascardi discorda de Cícero, por exemplo, quando o latino afirma que o estilo historiográfico se avizinha ao estilo sofístico ${ }^{8}$.

(...) nos mais historiadores não serve o discurso ao acaso; antes o caso tudo serve ao discurso, sendo contado como acaso tudo o que se conta. É bem verdade que a História se quer vestida e revestida de juízos, sentenças, secretos, malícias e descrições; porque, enfim, uma História nua, sobre desonesta, é desproveitada. Isso vos dizia Agostino Mascardi, que melhor o escreveu do que o observou?.

Ou quando, na voz de Bocalino, refere-se a Mascardi como autor "da Arte Historiográfica, livro de grande e bem logrado estudo", observação à qual retruca Quevedo, personificado nos diálogos de Francisco Manuel de Melo: “(...) Pois, sem embargo de ser o mestre dessa Arte, também ele pecou em Adão no outro seu opúsculo da conjuração desse mental tirano de Gênova, o Conde João Luís de Fieschi. (...)" ${ }^{10}$. Meneses, por sua vez, no "Prólogo" de sua História, explica que: 
(...) Antes que começasse a escrevê-la (...) [passou] (...) por espaço de dois anos as histórias mais seletas antigas e modernas, conhecendo que era necessário assentar o estilo; porque não tendo seguido mais escolas que as militares, que não costumam deixar à lição dos livros muitas horas de exercício, haviam levado a inclinação a equívocos e termos poéticos, frase de que os primeiros anos mais continuamente se alimentaram, e de que (...) [o fez] (...) apartar o mais que (...) possível a doutrina dos mestres da história, e a dos preceitos históricos de Mascarde (sic), italiano, e do Padre Mene (sic), francês, que nesta idade com grande elegância se empregaram neste assunto. (... $)^{11}$.

Uma dessas honras seiscentistas atribuídas às obras é a de ser citada, mesmo que para discussão, reparos, emendas, comentários e possíveis refutaçóes, como o mesmo Mascardi faz com as autoridades de seu texto, principalmente Cícero, e como fazem os outros letrados quando lêem sua arte.

Outra recepção seiscentista é possível de ser pensada. O Padre Antônio Vieira pode ter tomado contato com os ensinamentos historiográficos de Mascardi, uma vez que, como se sabe, por testemunho seu em carta $^{12}$, foi leitor da História de Portugal Restaurado. Ocorre que o Conde vale-se da arte de Mascardi, aplicando-lhe as prescrições para compor sua história da restauração de Portugal, como visto. No mínimo, Vieira conheceu a recepção contida no livro do $3^{\circ}$ Conde da Ericeira, mesmo que em idade longeva. Vieira pode ter tido contato com as obras de Mascardi, em virtude de ter estado em Roma, como se sabe, e por Mascardi estar diretamente ligado a Urbano VIII.

Por outro lado, nada impede que a Arte Histórica tenha circulado em meios jesuíticos ibéricos e não só em ordens como as da Santa Cruz de Coimbra, uma vez que Agostino Mascardi foi ex-jesuíta, como se disse, e moralizou catolicamente, em termos providencialistas contrareformistas e anti-heréticos, sua preceptiva e, principalmente, a preceptiva dos poemas neolatinos e italianos de Urbano VIII.

O ambiente letrado do genovês é o do Colégio Romano neolatino, em que o Professor de retórica do Papa é o Padre Famiano Strada, referido acima, responsável por instruir sobre o trono de Pedro um dos mais dóceis discípulos da "musa cristã da Companhia de Jesus", como entende Fumaroli ${ }^{13}$. Bertelli mostra como “(...) a Roma da Igreja Católica soube preparar no- 
vas orientações historiográficas, e para nenhum desses escritores ['novos'] existiu nenhum significado o problema de liberdade de expressão, como o que interessou a Patrizi e a Mascardi (...)"14.

Mesmo assim, os preceitos contidos na Arte de Mascardi são reposições de preceitos antigos do gênero histórico, principalmente latinos, em termos de inventio, dispositio, elocutio, amplificatio etc. Ou seja, Mascardi repõe prescrições que circulavam, no século XVII, em várias artes da palavra moralizadas pelas interpretações teológico-políticas com as quais se prescreviam os modos de preencher as tópicas tradicionais do uso do gênero historiográfico com as matérias históricas narradas do tempo e da interpretação providencialista que se extraía delas. Portanto, tópicas conhecidas, formuladas e praticadas, em reedição, mesmo que Vieira, por exemplo, nunca tenha lido a Arte Histórica de Agostino Mascardi, - o que menos interessa, com certeza. A formação jesuítica a que os letrados seiscentistas eram submetidos previa conhecimentos coletivos. Nesse sentido, a preceptiva é uma particularização de práticas coletivas ibérico-italianas seiscentistas e não uma mera aplicação dedutiva de categorias positivas sobre história.

Sabe-se, no entanto, de um exemplar da edição de 1674 do Dell'Arte Historica que pertence ao acervo da Biblioteca Nacional do Rio de Janeiro. Com essa informação, pode-se também tentar entender a circulação de Mascardi em Portugal, para além da circulação seiscentista referida, e no Brasil, a partir do início do século XIX, uma vez que parte principal do acervo da BNRJ se constitui de volumes da Biblioteca de D. João VI.

Ou seja, Mascardi foi lido em Portugal nos séculos XVII e XVIII, depois foi trazido para o Brasil pela corte de D. João VI, se não o fora antes pela Companhia de Jesus. Os acervos, cujas instituiçóes abrigaram e/ou abrigam exemplares da Arte Histórica, em Portugal e no Brasil, são eclesiásticos ou cortesãos, sugerindo que Mascardi foi lido por padres e príncipes, a quem convinham, neste tempo, a leitura e o exercício dos preceitos de uma Arte Histórica, por se tratar de gênero demonstrativodeliberativo, cuja função é a de aconselhar. Além, é claro, do círculo de letrados e militares que, como a recepção seiscentista mencionada, podem atestar também a circulação do gênero estudado e da arte referida. 
Antes de fazer referências à circulação dessa arte no século XVIII, convém lembrar que o tratado de Mascardi recebeu, ainda no século XVII, outras duas leituras, além das citadas acima. A primeira é a licença concedida e recomendação de publicação por Angelo Gallucci, da Companhia de Jesus. Nela o examinador diz que a preceptiva de Mascardi é “(...) utilíssima, não só aos escritores de história, mas também aos oradores sacros e profanos, aos poetas, e professores de Belas Letras, e a todas as pessoas de engenho, e sabedoria (...)". Adverte que leu a arte em questão por recomendação do Padre Mestre do Palácio Sagrado. O Padre examinou o tal livro, não encontrando nele “(...) nada que repudiasse a Fé e os bons costumes (...)”. [Tem Mascardi] “(...) copioso em erudição, assim como em estatura e vivacidade de estilo (...)". [Sendo] “(...) bem fundados seus ensinamentos (...)”15. A segunda é de Tomaso Tomasi, como lembra Sérgio Bertelli: “(...) En otro escrito, Il Principe Studioso, el mismo autor [Tomaso Tomasi] había llamado a Mascardi 'honor de nuestro siglo', y ateniéndose a sus preceptos utilizará también él aderezos imaginarios para dar vida al relato, pero también incluirá documentos en el texto, dando muestras de estar bien informado (...)"16.

No século XVIII, ao que parece, não houve nenhuma edição da preceptiva historiográfica de Mascardi, porém escreveu-se sobre o historiador e preceptista pelo menos em duas publicaçōes localizadas ${ }^{17}$. A ausência de impressões dessa Arte no século XVIII é significativa, tanto quanto a ampla difusão que dela houve, no século XVII. As edições de final do século XVII, como a de 1674, devem ter circulado ao menos até meados do século XVIII. Por mais que se tenham alargado as leituras da preceptiva de Mascardi com as idéias iluministas, circulando em maior profusão, não se justificou mais editar tal tratado no século XVIII em diante, a não ser em reedições facsimilares do século XIX. A Arte Histórica passou, então, a ser verbete enciclopédico, quase esquecida.

Do século XIX até hoje, são conhecidas três edições "anastáticas", uma de 1859 , duas de $1994^{18}$, reedições da primeira delas citada, provavelmente, e cinco verbetes sobre o preceptista em enciclopédias, três italianas, uma francesa e outra espanhola ${ }^{19}$. Ao que parece, as leituras ibéricas da Arte Histórica ficaram restritas às feitas no século XVII, uma vez 
que, até hoje, não se encontrou nenhuma recepção dela nem em Portugal nem na Espanha, que não as já citadas.

No Brasil, com a exceção de duas referências pontuais a Mascardi em uma tese de doutorado ${ }^{20}$, a crítica e os historiadores parecem desconhecer o Dell' Arte Historica. Nos anos 50 do século passado, Masca Bettarini redigiu, na Itália, um estudo monográfico sobre Mascardii ${ }^{21}$. Não fosse a biografia de Mascardi escrita por Manucci ${ }^{22}$, em 1908, o estudo monográfico teria sido precursor na pesquisa sobre o genovês, no século XX. Nos anos 70 do século passado, Sérgio Bertelli lê a preceptiva de Mascardi, ao estudar práticas letradas seiscentistas nas polêmicas italianas da agudeza:

(...) Es cierto que Arte historica no gozó de la característica de la originalidad; sin embargo, la fortuna le fue favorable porque logró hacerse intérprete de la exaltación de la historiografia ligera - con lo que entraba en el grupo de los antitacitistas moralizantes - pero exaltando al mismo tiempo una historiografía 'civil' como la guicciardiniana, y, lo que es más, retomando la temática escéptica de Patrizi, cuya mediación buscaba. Tampoco se negó a las contiendas literarias, a las que más bien reservó una larga disquisición sobre problemas estilísticos (Della strutura dell'historia), que era un tratado dentro del tratado y en la cual, en polémica con Castelvetro, sostuvo los criterios de la retórica del siglo XVII. Pero también aceptó los discursos imaginarios (e insultó al pobre Bastian Maci da Castel Durante, que los habia reprobado), asi como denostó [cic] la elegancia de la ornamentación, a fin de que fueran puestos al servicio de la utilidad de la enseñaza histórica (... $)^{23}$.

Na última década do século passado, o francês Marc Fumaroli fornece informações um pouco mais precisas sobre o letrado, como foram citadas anteriormente. $\mathrm{O}$ ensaio de Eraldo Bellini parece fechar o círculo das pesquisas sobre o genovês e o Dell'Arte Historica ${ }^{24}$ até o momento.

\section{Astúcias de Mercúrio}

No Prólogo ao leitor do Dell'Arte Historica, Agostino Mascardi adverte sobre o propósito de estabelecer preceitos para que as histórias sejam fabricadas. As auctoritates com as quais o preceptista fundamenta seus propósitos, seus modelos de imitação e emulação, discussão, refutação etc. são nomeadamente antigos retores, oradores, historiadores, poetas, como 
Aristóteles, Cícero, Plínio (o velho), Plutarco, Tácito, Platão, Políbio, Dionísio de Halicarnasso, Luciano de Samósata, Virgílio, Longino, entre outros e letrados contemporâneos seus, como Castelvetro, Pallavicino etc. Além do prólogo, a preceptiva tem quatro tipos de imprimatur que se repetem, pois colocados no início do volume e no final. Os quatro assinados pelo Reverendíssimo Padre Mestre Sagrado do Palácio Apostólico e pelo Frei Nicolaus Riccardius Sac. Pal. Apost. Mag. Ordinis Praedicatorum.

O Dell'Arte Historica se divide em cinco tratados. O primeiro tratado subdivide-se em cinco capítulos. O segundo, em oito capítulos. O terceiro, em cinco. $\mathrm{O}$ quarto tratado se divide em cinco partículas e o quinto, em nove capítulos, dos quais vários se subdividem ainda em partículas, totalizando 676 páginas numeradas, além das 34 páginas sem numeração, onde se localiza o índice das matérias. Trata-se de uma encadernação in $4^{\circ}$, acompanhada de um frontispício, cuja inscrição é Libertas.

O primeiro capítulo do primeiro tratado, "Que coisa é a história, sua origem, e antigüidade" 25 , dedica-se ao estudo do "modo de bem escrever uma história”, com o exemplo das "grandes" autoridades antigas: “(...) que os ensinamentos direcionados à prática, para auxiliar-me, e a qualquer um que fosse desejoso nestes estudos, o modo de bem compor uma história, sob o exemplo dos grandes antigos (...)"26.

Mascardi prescreve os modos adequados de dispor a história e, conseqüentemente, formá-la, indicando, portanto, que se ocupará da dispositio retórico-historiográfica ainda no primeiro tratado da preceptiva: “(...) a matéria, em torno da qual trabalha o historiador nas suas narrações/descrições, deve mostrar o modo de bem dispô-la e formá-la (...)"27. Define história como 'res gesta, sed ab aetatis nostre memoria remota', citando Cícero e a Retórica a Herênio (M. Túlio, Lib. I "De Inventione”; Lib. I Retórica ad Herennium). Amplifica a noção latina, ao propor a história como aquela que

(...) define uma seqüência de narrações, harmoniosamente entrelaçadas, pode por ventura dizer sobre a verdade, nem por isso fica incompleto o conjunto, ou confuso: porque muitas narraçôes de contadores de fábulas com bela arte se entrelaçam, que nem por isso história são realmente (...)"28.

Aponta que distinguirá a história dos anais e dos comentários. A arte histórica tem como finalidade "ensinar a narrar a história dos acidentes humanos muito memoráveis" 29 . 
O segundo capítulo do primeiro tratado, "O que é próprio do ofício de escrever a história para diversas nações"30, ocupa-se em definir o ofício do compositor de histórias, sendo que define história como "aquilo que é digno de se registrar na memória”31. Mascardi diz que "(...) o ofício de compositor da história, [é] freqüentemente comprometer-se com personagens de excelente qualidade, e com soberanas dignidades merecedores de reverências" $(. . .)^{32}$.

O terceiro capítulo do primeiro tratado, por sua vez, é um dos mais relevantes entre todos. Ou seja, "Da divisão da história em efemérides, anais, cronologia, comentário, vida" ${ }^{33}$, é o capítulo que prescreve os subgêneros históricos

(...) Assim nasceram as Efemérides, ou melhor dizendo os Diários, os Anais, as Crônicas, os Comentários, e as Vidas, que se nomeiam histórias (...), para que todas sirvam para eternizar as memórias dos acontecimentos passados, para o ensino da posteridade $(. . .)^{34}$.

Pela própria significação do termo latino, efemérides, ou pela voz grega, Mascardi, define esse subgênero historiográfico como uma “(...) escritura (...)", na qual as coisas decorrem no tempo de um dia. Nesse subgênero, cabem matérias infinitas, desde que se respeite, de um modo ou de outro, como varietas, o registro dos acidentes de uma jornada de um $\mathrm{dia}^{35}$.

Decorrem dessa noção outras duas, ou seja, o jornal e o calendário. Mascardi prescreve a primeira como sendo um tipo de efeméride mercantil, no qual se escrevem os créditos e os débitos no livro da razão. Efeméride é o subgênero historiográfico na voz grega, enquanto calendário o é na latina e, segundo o genovês, são pares correspondentes ${ }^{36}$. Quanto ao comentário, Mascardi diz “(...) não ser nada mais que as Efemérides, e nomeadamente na qual César, disse: - falando da fraude, com que o Germano rompeu a trégua - Fomos assaltados (...)" ${ }^{37}$.

Por ser formada de ações, as quais o escritor deve bem dispor em matérias para formar uma história, a efeméride é comentário dos dias ${ }^{38}$. Os anais, por sua vez, são subgêneros historiográficos na medida em que Mascardi os entende como uma narrativa das coisas singulares de um ano ${ }^{39}$. 
Contestando Gélio das Noites Áticas, Mascardi prescreve as efemérides subordinadas aos anais, pois elas comporiam as narrativas dos anos. A auctoritas refutada concebe, segundo o preceptista, as efemérides como espécies dos anais. Tem-se, aqui, uma emulação, que é refutação somente como tópica, uma vez que espécie e relação de subordinação diferem apenas porque, ao imitar o modelo, na emulação, Mascardi coloca as categorias em relação também de hierarquia, não proposta por Gélio ${ }^{40}$. Trocando em miúdos, a doutrina diferencia imitação de açôes para memória de um dia e imitação de açōes de um ano, na relação dias/anos. Para finalizar o capítulo, o genovês diferencia história de anais, de crônica e de vida:

(...) A diferença trazida depois por Sérvio, que quer que a História seja um relato dos eventos vistos e interpretados pelo escritor, que o Anal seja uma narração dos acontecimentos do nosso tempo, (...), como não recebida, nem dos costumes dos bons, nem da razão, que a sustém, deixamo-la voluntariamente, parecendo-nos pelo estilo da escrita refletir o passado do ano, e de qualquer parte da matéria menor, possam os Anais suficientemente distinguirem-se da história (...). Sobre as Crônicas, diremos pois somente, sobre a sua natureza, que não seja outra que a história dos tempos (...), onde os livros de Crônicas apóiam-se (...) Resta agora, que se observe algo sobre as Vidas, e daria matéria não somente deleitosa, mas necessária (...) e especialmente aquelas, que relatam as ações dos homens santos: quais freqüentemente, capturariam os olhos e o ânimo dos leitores com a maravilha devida à virtude que transpóe os limites da fraqueza humana; tanto pela imperícia, ou pela verbosidade de quem fabrica mil discursos vazios $(. . .)^{41}$.

O subgênero "vida", nesse sentido, é aquele que Mascardi mais preenche de explicações. O preceptista define a utilidade desse subgênero em regular os costumes, devendo-se fazer a composição da persona a partir das ações mais longínquas, desde o nascimento, até as mais recentes, do fim da vida. Lembra ao escritor de história que as vidas que interessam são as dos homens de guerra dotados de eminentes virtudes, com as quais se pode despertar no leitor a imagem virtuosa exemplar ${ }^{42}$ :

(...) saiba primeiramente quem escreve uma vida, o faz para regular o costume, da história se traz (...), pode-se relacionar com vidas dos homens guarnecidos de eminente virtude (...) e conduzindo o seu personagem desde seu nascimento à sua queda $(. . .)^{43}$. 
O quarto capítulo do primeiro tratado, "Da matéria da história" ${ }^{44}$, estabelece a guerra como a tópica por excelência da história, cuja interpretação é providencialista, uma vez que Mascardi a entende conduzida por Deus, fazendo várias considerações teológicas para ocasiōes de guerra e explicando o que leva o historiador a narrar sobre guerra ${ }^{45}$. Além de moralizar a tópica, o preceptista discorre sobre o decoro historiográfico e o porquê de se escrever história, discorrendo sobre cronologia e história e propondo a geografia, e "sua natureza", como argumento da história. São argumentos historiográficos as descriçōes e as pinturas de história ${ }^{46}$ : “(...) $\mathrm{Na}$ geografia de sua natureza é argumento de história, tudo que o possa ser por evento; porque se na descrição dos lugares, como leva o nome, emprega-se, (...) não faz mais justamente que narração histórica (...)”. A geografia (...) é uma imitação de uma pintura da totalidade das terras conhecidas $(. . .)^{47}$.

Em contrapartida, Mascardi discute a finalidade da história e se é possível reduzi-la à arte, no quinto e último capítulo do primeiro tratado, intitulado "Define-se a história e se é possível reduzi-la à arte" ${ }^{\text {". }}$. Para argumentar em favor de suas proposições, entre outras coisas, nesse capítulo, o ex-jesuíta genovês autoriza-se, mencionando outras artes históricas, como a de Luciano de Samósata, que lhe permitem defender a história como arte em semelhança à arte retórica de Quintiliano. Para o preceptista, ao mesmo tempo em que sua arte se aproxima da Instituição Oratória, distingue-se em especificidade ${ }^{49}$.

(...) Resta agora para justificar o título do livro, para examinar se a história está sob preceitos da arte, isto é dizer se é possível prescrever regras certas, que com o auxílio das quais outro componha artificiosamente a história (...). Escrevo sobre arte histórica assim como Quintiliano, quando escrevia sobre a arte retórica $(. . .)^{50}$.

No primeiro capítulo do segundo tratado, "Da verdade da história"51, Mascardi entende a verdade como fundamento "da fé pública”, examinando Platão, Tácito, entre outros, autorizando-se em Quintiliano. Depois, autoriza-se em Políbio, afirmando ser "a verdade os óculos da história” 52 , e em Cícero, com a máxima lux veritatis. Aqui, Mascardi prescreve as diferenças entre poesia e história, diferenciando-as por serem confec- 
cionadas a partir uma, da fábula, enquanto a outra, da verdade ${ }^{53}$. “(...) Assim como o fundamento da fé pública nos interesses civis, depende da pena dos escritores, assim o historiador deve estudar, para que nos seus escritos tenha lugar incontaminado e sincero (...)" 54 .

Em seguida, no segundo capítulo do segundo tratado, "Onde nasce a falsidade da história, e como se deve tal reversão desse castigo, tal volta de compaixão" ${ }^{55}$, Mascardi traça relações da verdade da história com o príncipe e com a diplomacia. Exemplifica essas relações com a discussão e transcrição de uma carta diplomática de um ministro de Estado. Interessa pensar que Agostino Mascardi ressalta que a “(...) fé que se presta à história é a fé humana, isto é, sempre junto com a dúvida, já que na essência não se afasta da opinião. Então, injuriado o leitor, pede do historiador a certeza infalível, apoiada na autoridade que não aceite contraste (...)" ${ }^{56}$.

Ressalva que pode ser lida como advertência ou como prescrição que dita o uso dos opináveis, endoxa, que, aceitos como verdadeiros, autorizam-se e autorizam o discurso. Essa noção articula-se com a definição da verdade como "óculos da história", uma vez que verdade autorizada. As relações entre o ethos elevado de tipos como os cortesãos, príncipes e diplomatas e a arte histórica são definidas pelo tipo de função, do gênero e suas exigências de verdade. Como tipos superiores, próprios não só para a condução dos negócios, mas aptos para, autorizados, reatualizar, “(...) pela fé divina, a verdade indubitável, quanto da divindade que a revela (...)" 57 . Esses tipos seriam os que, com maior precisão, confiariam maior credibilidade para suas palavras, pois “(...) sábios e de conhecida bondade e que por escolha não mentem (...)" 58 .

O terceiro capítulo do segundo tratado, "Alguma regra da verdade, que na história se requer necessária" 59 , explica que a história "é espelho da humanidade" e, ao emular várias artes antigas da pintura e da palavra, prescreve os pintores Polignoto e Dionísio como pintores, poeta o primeiro e, historiador o segundo, mobilizando noções de pintura, poesia e história ${ }^{60}$ :

(...) Este primeiro ensinamento, de não contaminar a candidez da verdade com mentiras, é necessário que, segundo o sentimento de Timeu citado por Políbio, a história perde sua natureza, se perde a verdade. Espelho da vida humana é a história, mas se o espelho não mostra imagem de rosto semelhante ao oposto exemplo, nem pode chamar-se espelho, nem a figu- 
ra, que representa, por imagem se reconhece. Polignoto e Dionísio foram pintores excelentes, mas o primeiro formava com arte os retratos mais belos que a natureza não havia fabricado (...); o segundo colocava todo o engenho em transportar um rosto para sua tela. Polignoto ao meu parecer é símbolo do poeta (...). Dionísio é o historiador que religiosamente propaga à posteridade a simples semelhança da verdade $(. . .)^{61}$.

Mobilizando conceitos como os da poesia como pintura e da história como pintura, tópica retórico-poética que circula por muitas artes da palavra e artes pictóricas, Mascardi afirma haver perda da natureza da história, quando esta se afasta da verdade, pois a verdade é a própria natureza da arte histórica. Nesse sentido, aproxima ou afasta os pintores, distinguindo-os. Polignoto é poeta, porque “(...) colocava seu engenho para bordar um vulto nas suas telas (...)"62, enquanto que Dionísio é historiador, na medida em que não fere a verdade, pintando a natureza como foi fabricada.

O quarto capítulo do segundo tratado, "Da digressão na história, e se é possível dizer que ofendemos a verdade" ${ }^{63}$, discute conceitos de verdade e de verossimilhança na história. Em semelhança com a pintura, a digressão é técnica descritivo-enunciativa de visualizar o discurso. Nesse sentido, a leitura desse capítulo pode se relacionar com o anterior, na medida em que são prescrições historiográficas que aproximam os discursos da história das pinturas de história, embora Mascardi não formule o ut pictura poesis, muito menos cite Horácio. Como descrição epidítica ecfrásica, que faz ver, a referência latina para a tópica da pintura como poesia e da poesia como pintura pode ser inferida. Com relação à verossimilhança, Mascardi preceitua duas "sortes" de verossímil. Um que "guarda o falso". Outro, "o verdadeiro" "64: “(...) Este verossímil, que em torno de matéria falsa orbita, falso se chama igualmente (...). Então, este verossímil, que se conforma com o feito, se chama verdadeiro (...)" ${ }^{65}$.

Para demonstrar a proposição, exemplifica com Virgílio sem referenciar a passagem, mas sintetizando-a ao mencionar a Rainha dos cartagineses e Enéias e uma passagem retirada da história sobre Cipião na narrativa de Políbio. Define o verossímil de Virgílio como "falso", porque de variante poética (da poesia). Define o verossímil de Políbio como "verdadeiro", historiador, histórico: 
(...) Finge Virgílio, à guisa de exemplo, Dido a rainha de Cartago apaixonada por Enéias, que abandonada, e traída, furiosamente, mata-se. $\mathrm{O}$ feito é todo falso, (...) retém contudo aquilo, a semelhança com a verdade (...). Ao contrário Cipião, (...), vê uma belíssima donzela na multidão de prisioneiros, e podia usar o fruto da vitória subjugando-a para seu prazer, ele porém (...) com as leis da razão conserva inviolada a donzela (...). O feito é verdadeiro, mas parcamente verossímil (...).

Mais do que variações de eixos poéticos e históricos, as duas sortes ou tipos de verossímeis respeitam, cada uma, a seguinte noção: o verossímil que se constitui em torno da matéria falsa chama-se falso, enquanto que aquele que se conforma com feitos se chama verdadeiro ${ }^{67}$. Mascardi prescreve, assim, uma espécie de verossímil de 'feitos'.

Em continuidade ao capítulo anterior, o quinto capítulo do segundo tratado, "A segunda regra da verdade histórica" 68 , lembrando-se que a primeira regra foi descrita no capítulo IV, citado acima, debate a matéria examinando auctoritates como Plínio, Platão e Gélio. Particulariza a discussão lendo alguns passos da História do Concílio (...), de Nicolò Damasceno.

Por sua vez, no sexto capítulo do segundo tratado, "Se ao escritor de história devemos atribuir operações iníquas [?] e de que modo se deve fazer para não trair a proibição de Túlio" ${ }^{69}$, Mascardi repõe a máxima ciceroniana que define a história como magistra vitae ${ }^{70}$, afirmando que “(...) se escreve história (...) para formar no ânimo de quem lê o simulacro da virtude, imitado dos exemplos de tantos ínclitos heróis" ${ }^{71}$.

Citando Dionísio de Halicarnasso, explica a filosofia do exemplo, ensinando que "a história é uma filosofia composta de exemplos": “(...) de filosofia do exemplo chamou Dionísio de Halicarnasso a história (...)”72.

A eficácia de tal procedimento imita o modelo, quando o letrado, que se ocupa do gênero historiográfico, vale-se, em meio à narração, de aforismos cuja utilidade se aplica ao historiador e ao príncipe. Termina esse capítulo com a conclusão, em forma de epifonema, de que "não haveria mundo sem história"73.

O sétimo capítulo do segundo tratado examina a "Terceira regra de Túlio"74 acerca da verdade histórica. Nele, Mascardi discorre sobre paixões, prescrevendo três modos de mover na utilidade e utilização da história, isto é, por adulação, por medo de vingança e por amor: 
(...) A primeira seria por adulação (...) especialmente dos Grandes; com o qual cada espírito, cada beleza da verdade histórica contamina-se, e corrompe-se (...). Porque a adulação e o medo são quase partes gêmeas de um ânimo servil (...). Concluo, então, com Políbio, que ter amor à pátria, aos amigos, aos pais faz parte da natureza do homem de bem $(. . .)^{75}$.

O oitavo e último capítulo do segundo tratado, "Da última regra da verdade ensinada por Cícero" ${ }^{\prime 6}$, debate sobre a imitação da aparência, examinando Platão do Górgias, principalmente ${ }^{77}$ :

(...) É tão tênue a sagacidade dos homens que não é raramente no julgamento ser enganada pelas aparências, com a manifesta injúria do intelecto bem regulado, porque sendo resvaladiça a fronteira das coisas, a semelhança às vezes engana o zelo de quem almeja plenamente discernir a verdade. Discorre sobre isso doutamente Platão, e traz a diferença, que se deve repor entre as artes (...), para não errar, não menos ao cultivo do ânimo, que à cura do corpo destinados, e aqueles que com falsa aparência imitando-as corrompem-na $(\ldots)^{78}$.

O terceiro tratado do Dell' Arte Historica, "Da política histórica”79, argumenta a favor de uma política no corpo da história, pressupondo a história como "verdadeiro livro de príncipes, com a qual se doutrina o governante" ${ }^{80}$. Recomenda que para se escrever uma história seja necessária uma elocução afastada do ordinário, que não perca os nexos, as correspondências das partes/todo no corpo da história. Deve o historiador abandonar o ódio e aproveitar a ocasiāo de disputa, demonstrando maturidade e perfeição nos juízos ${ }^{81}$. Prescreve o uso das efemérides, dos diários, para os príncipes, capitães e outros homens de Estado ${ }^{82}$.

No primeiro capítulo do terceiro tratado, "Se é da responsabilidade do homem político escrever a história e de que modo" ${ }^{33}$, Agostino Mascardi elege como uma das matérias discutir "a guerra como origem das coisas e, portanto, especialmente grande matéria do historiador":

(...) A guerra dá a luz a estranhos e impensados acontecimentos, os quais, pela novidade são maravilhosos, pela freqüência inumeráveis, e pela atrocidade compaixão, deram ocasião ao antigo provérbio dos gregos ('Bellum omnium pater'). ['A guerra pai de tudo']. Mas nenhum parto mais monstruoso dela se propaga, que a infinita prole dos historiadores, que de uma só vez vem à luz do mundo (...)" ${ }^{\text {"4 }}$. 
Entre outras tópicas, debate a qualidade elocutiva necessária ao bom compositor de histórias, regulando o engenho por meio de um perfeito juízo:

(...) Escreve histórias aquele que porventura nunca tenha lido outro historiador, como Palmerino d' Oliva, e Florestano; que não tem estudo de eloqüência e exercício do estilo; que nunca adquiriu hábito algum de prudência civil, que não saiba o que seja a elocução; que não conhece a ordem na escrita; que não entende a correspondência das partes em todo o corpo da história; em suma, que por prurido do engenho e talvez também pela abundância do ócio, abraça por motivo de divertimento aquele que não está bem sem longuíssimo estudo por um maduro e perfeito juízo (...)[?] ${ }^{85}$.

Indica tipos de homens que, por sua ocupação, função, cargo ou instituição a que pertençam, seriam os mais aptos historiadores. Esses tipos seriam príncipes, capitães e outros homens de Estado, como os validos e conselheiros de príncipes. Argumenta em favor da aptidão que esses agentes históricos teriam, uma vez dotados de temperamento diverso do temperamento dos poetas: “(...) melhor pode satisfazer a obrigação de um bom Historiador, um Príncipe, um Capitão, ou outro homem de Estado, do que uma pessoa privada, ainda que bem guarnecida de bom juízo, ou de suficiente conhecimento das coisas do mundo (...)" ${ }^{\text {86 }}$.

A noção política que Mascardi veicula em seu tratado é a da conhecidíssima metáfora aristotélico-escolástica do corpo político dotado de cabeça (rei) e tronco, membros (súditos, alienados no pacto de sujeição), que doutrina e constitui o Estado do Antigo Regime. Para além dessas considerações sobre esse capítulo, interessam muitíssimo outras formulações prescritivas sobre efemérides como variação do subgênero diário em relação com pessoas públicas, como príncipes e capitães ${ }^{87}$ : “(...) Dos Príncipes, dos Capitães, e dos homens de Estado gritarei as efemérides, ou como costumam chamar os diários, que oferecem oportunamente a silva ao historiador (...)" 88 .

O segundo capítulo do terceiro tratado, "Que dependência se pode estabelecer entre a história e a filosofia civil" ${ }^{99}$, ocupa-se não só do discurso historiográfico, mas traça paralelos com a pintura, conceituando-a como "história muda":

(...) Quatro eram, pelo que soube observar, os graus da boa educação, por meio dos exemplos; e quatro os instrumentos dos quais se valiam os nossos 
grandes. A Pintura, a Poesia, a História, e a Filosofia. Da pintura foi dito sabiamente, tinha o povo como mestre; mas se pode dizer dela paralelamente, que ela é regente do povo; pois os homens vulgares, que são mal guarnecidos de entendimento, e das letras e as crianças, que nessa parte devem ser enumeradas com o povo (...), não têm outro livro se não a pintura, a qual os acontecimentos passados com as cores representam, vem à maneira de história muda para insinuar nos ânimos tacanhos, por meio dos olhos, o exemplo do bem, ou do mal (... $)^{90}$.

Reafirma noções já trabalhadas como as que conceituam a história

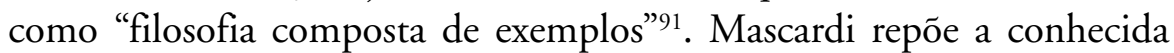
frase de Gregório Magno que diz que a pintura é a Bíblia do ignorante. $\mathrm{Na}$ emulação, formula que a pintura é mestra do povo, dos homens vulgares, mal formados no entendimento das letras. Com os olhos pode-se seguir os bons e maus exemplos, tanto quanto com os ouvidos ${ }^{92}$.

O terceiro capítulo do terceiro tratado, "Como deve ser lida a história e se se compõe mais louvavelmente misturada com a narração de sua lição" "33, preceitua os dois modos mais decorosos para ler o gênero: segundo os costumes e segundo o modo prolongado no compor.

Prescreve, ainda, o uso da genealogia, pois a serviço do encômio dos capitães, mestres de campo. O modelo é o das vidas, imitação ciceroniana de excelências e um dos lugares de pessoa prescritos por Quintiliano ${ }^{94}$ :

(...) Sendo assim, devendo o historiador, que vou todavia formando, polirse à maneira dos escritores excelentes, aprendendo mais pela sua imitação do que dos ensinamentos de quem quer que seja; não se desdiz prescreverlhe o modo de aprender enquanto os lê (...) para que não ande em vão peregrinando o engenho fora do caminho régio por trilhas duvidosas, cuja saída quase sempre não se prevê (... $)^{95}$.

O quarto capítulo do terceiro tratado, "Da digressão especialmente política, e a que lugar reside na história" ${ }^{\prime \prime}$, faz uma divisão útil sobre episódio narrativo. O preceptista divide episódio em poético e oratório, episódio ou sua digressão, que também se divide em poética e oratória. Ou seja, na oratória utiliza-se da digressão oratória e na poética a digressão poética, de acordo com os tipos de episódios que se narram. Mascardi entende "episódio" como tudo que se refere a algo fora do propósito narrativo principal. Na poesia, o episódio fabuloso deve ser proporcionalmente mesclado 
com as demais partes narrativas, sem que se comprometam as correspondências. A digressão oratória se dá por razões civis, de usos judiciários, cuja finalidade é levantar o ânimo do auditório e dos juízes:

(...) A digressão, assim chamada na Itália pelos mais elegantes, prosadores e poetas, nos idiomas estrangeiros recebe diversos nomes, que todos querem trazê-lo a exame, para não deixar também uma sombra de dúvida, que tornasse menos clara a doutrina deste capítulo. Egressus, ou egressio foi chamada pelos latinos, como se vê em Quintiliano, e também exessus por sentimento de Sérvio (... $)^{97}$. (...) Pode-se chamar episódio aquilo que também autoriza Pólux no onomástico, que o define uma coisa adventícia e inserida em outra (...), a música nos diálogos, a comédia nas núpcias poderão chamar-se episódio, e assim o chama Plutarco $(. . .)^{98}$.

O objetivo nesse capítulo, entretanto, é o de definir o uso da digressão historiográfica mais próxima da oratória que da poesia, uma vez que, citando Quintiliano, Mascardi prescreve o uso desse recurso narrativo, que chama de instrumento utilíssimo da retórica:

(...) A digressão oratória, dita por Quintiliano egressus e egressio dos gregos (...) define-se, 'alienae rei, sed ad utilitatem causae pertinentis, extra ordinem excurrens tractatio'. Mesmo que anteriormente originada pela ostentação dos antigos declamadores, aprovada, porém, pouco a pouco pelo uso desceu às causas civis, e foi recebida ainda nos tribunais, mas parece que por um tempo que mais serviu à pompa dos advogados, do que à necessidade dos clientes (...) e, considerando que das digressões recebiam as causas, como levantar do ânimo do auditório, e do juíz já cansado do tédio da simples narração (...); com algumas poucas regras foi reduzida a ser agradabilíssimo instrumento da retórica $(. . .)^{99}$.

Mascardi discute a legitimidade de o historiador valer-se da digressão, justificando o uso por razões de utilidade e de deleite, de saber e fazer saber, pois a digressão histórica assemelha-se à verdade de suas matérias:

(...) Suposto tudo que foi dito, venho à matéria própria deste capítulo, e pergunto se o historiador pode se valer da digressão; uma vez que ao poeta e ao orador não muito procede nas suas composições a desventura. Negam isto absolutamente alguns autores modernos, e três razōes alegam para a doutrina que ensinam (...). A continuação das coisas, que em uma narração ordenada, quase com os olhos são vistas do leitor, não consente uma inter- 
rupção inoportuna, com o qual se distrai o ânimo de quem lê e fica privado do gosto, e em grande parte da utilidade, que se possa deduzir da história: e esta primeira razão tem alguma semelhança de verdade. A segunda é tão estulta que não ouso referi-la (...). Terceiro. Nem todas as digressões que se recebem dos autores devem ser aceitas de igual condição na história $(. . .)^{100}$.

Na medida certa, a digressão histórica provoca no leitor a justa curiosidade, iluminando a arte:

(...) $\mathrm{O}$ historiador não somente não peca contra a arte espalhando digressões pela história; mas despertará a justa curiosidade do leitor interrompendo o necessário; e privará da mais estimada luz da arte sua obra, não formando o louvável; como que possa abster-se daquilo, que se tolera; e deva fugir do último, que se recusa $(. . .)^{101}$.

Vários são, no entanto, os decoros digressivos historiográficos:

(...) Necessárias considero aquelas digressões, que vêm acompanhadas de alguma notícia, que tenha singularidade, e sem a qual muitos lugares da história ficariam mal resolvidos e obscuros. Incluo, neste total, a descrição de lugares, tempos, instrumentos, costumes das gentes, das formas de governo, dos costumes dos povos, das cerimônias nas coisas sagradas, e de outras particularidades; as quais se não precedem à narrativa dos fatos, $o$ leitor fica na escuridão, nem pode formar conceito suficiente sobre os ocorridos: porque muita coisa na textura da história de passagem se acena, as quais se deveriam largamente declarar-se naqueles lugares, viriam a interromper o fio da narração com o tédio; onde juntamente se relaciona àquela já passada, a qual põe os acontecimentos sob os olhos do leitor, como se pintados, e não narrados, ele as visse $(. . .)^{102}$.

No quinto e último capítulo do terceiro tratado, "Se do historiador podemos indagar a causa dos acidentes narrados e se a ele se deve o seu juízo" ${ }^{103}$, Mascardi prescreve, autorizado por Cícero do Orador, o uso da primeira pessoa historiográfica, sendo que o narrador-historiador não é narrador-auctor dos acidentes humanos narrados, mas juiz deles:

(...) Acrescenta-se a esta primeira liberdade concedida ao escritor da história uma segunda licença, não menos importante do que a passada, e com ela pela natureza estreitamente unida; e seja então ajuizar as ações, que acontecem na narrativa, ' $\&$ de consfilÿs significare, quid scriptor probet', 
disse (...) Cícero: cuja autoridade seguindo o doutíssimo Pontano, [auctor do Attio Sincero (diálogos)], constitui o historiador à maneira de Juíz, e talvez mais ampla lhe consinta a jurisdição daquilo que verdadeiramente lhe convenha $(. . .)^{104}$.

O quarto tratado, "Digressão sobre o estilo" ${ }^{105}$, legisla a favor dos vários usos da digressão em relação à elocução e ao estilo ${ }^{106}$. Divide-se em cinco partículas ${ }^{107}$. Intenta prescrever as regras do estilo para o historiador. Na partícula primeira, examina a palavra latina stilus, conceituandoo segundo seu uso seiscentista, ou seja,

(...) 'Stylus', ou, 'Stilus', de qualquer forma que se escreva segundo o sentimento natural, outra coisa não era que um instrumento por um lado agudo e do outro assaz largo que se usava para marcar nas tabuletas enceradas os caracteres, segundo o uso daqueles tempos, que, relacionando com o nosso século, com nosso uso, se diria instrumento para escrever $(\ldots)^{108}$.

Na partícula segunda, faz o exame da palavra grega, estilo, categorizando três estilos: magnífico, humilde e temperado, autorizando-se no que denomina "a maioria dos autores gregos e latinos"109:

(...) A maior parte dos autores, tanto gregos, quanto latinos, declara, que o caráter do dizer não é outra coisa, que não aquelas três famosas maneiras de falar (...) que são a magnífica, a humilde, e a temperada, as quais dividiremos a seu tempo (...). A elocução; ou seja quase gênero aplicado às três espécies antes mencionadas por nós, denominadas magnífica, humilde e temperada $(\ldots)^{110}$.

Na partícula terceira, debate sobre elocução e "se nela consiste o estilo"111:

(...) Mas somente na eleição, ou escolha das palavras, e no ornamento conduzí-las às figuras, a elocução consiste, nem que o estilo pode justamente nomear-se, nem todo corpo do falar virá por ela nobilitado, como convém (...). É, portanto, necessário, para reduzir à perfeita forma a elocução, que às palavras e às figuras algo se acrescente; em virtude de que o prestígio delas nas composições se reconheça; isto é dizer, por opinião de Dionísio de Halicarnasso, uma judiciosa colocação (...). A elocução, ainda que na sua essência perfeita, permanece, contudo, sem os carateres do dizer, e sem as formas, ou ornato das idéias da fábula, indeterminada e ociosa: sinal dela, que quando com a virtude e regras por nós assinaladas nestas partes uma boa redação se observa $(. . .)^{112}$. 
Na partícula quarta, ocupa-se dos caracteres maiores, médios e menores, prescrevendo "o modo adequado de se constituir o ethos" ${ }^{113}$ : “(...) Túlio nomeia o caráter mais elevado de grave, o menos elevado, atenuado, o do meio, medíocre, (...) humilde, temperado o chama (...)".

Explica ainda que a amplificação concorre a favor do caráter alto. $\mathrm{Ou}$ seja, quando se lança mão da amplificação nos discursos, sejam historiográficos, sejam poéticos, está-se constituindo o caráter alto ou grave: “(...) se as coisas grandes fossem de caráter Maior, as pequeninas do Menor argumento, e matéria, nenhum lugar teria a amplificação, que como dizia Isócrates, os baixos levanta, e as magnificantes abaixa (...)"114.

$\mathrm{Na}$ partícula quinta, prossegue relacionando ethos com estilo, ao se “(...) propor a olhar e declarar a natureza de ambos os conceitos que, por causa diversa do ethos, define-se ou se delibera (...)"115. Descreve, então, os modos de variar do ethos, prescrevendo sua diversidade segundo os estilos, dos quais privilegia o ethos e o estilo altos, que são os estilos e os caracteres mais adequados à história:

(...) Escrevo sobre arte histórica, e hoje não me avizinho a uma importante dúvida sobre o estilo mais proporcional, que com a doutrina da presente digressão será necessário decidir. (...) $\mathrm{O}$ caráter conveniente à história: porque não se tratando nela pelo menos, e segundo a conveniência, senão de matérias magníficas, e grandes, como as incumbências de Príncipes, e das Repúblicas; as guerras, a paz, as alteraçôes dos impérios, a mudança dos impérios, e coisas semelhantes; que somente do caráter magnífico fosse capaz a história $(. . .)^{116}$.

Na partícula sexta e última da "Digressão", Mascardi vai examinar "no que consiste o estilo", fornecendo quatro argumentos para a definição ${ }^{117}$ :

(...) De tudo isto que até agora discerniu-se, chega-se a alguns corolários, com os quais se termina esta digressão. Primeiro. O estilo é uma maneira particular, e própria de raciocinar, ou de escrever, que nasce do particular engenho de cada compositor, na aplicação e no uso dos caráteres na fala. Segundo. Comparado o caráter com o estilo, se este vem da parte da natureza e do engenho, aquele refere-se à arte, e ao estudo. E em conseqüência este se multiplica, e varia segundo o número, e a qualidade dos engenhos (...). Terceiro. Interrogar alguém em que estilo escreve é tolice, porque não pode em outro estilo compor, que não no seu próprio, ditado pelo enge- 
nho; se não, enquanto que com a imitação pode estudar e exprimi-la com alguma semelhança o estilo alheio; onde para que a interrogação não seja despropositada, se deva dizer, em que caráter escreva; quando contudo sobre imitação não se deduz. Quarto. Bem se pode dizer que aquele é o estilo de Tucídides e de Salústio, mas não que este é o caráter de Tucídides, e de Salústio; porque o caráter é comum a todos, e não próprio de Tucídides, ou de Salústio, como é o estilo (...) $)^{118}$.

O quinto tratado do Dell' Arte Historica intitula-se "Da estrutura da história" ${ }^{119}$, dividindo-se em nove capítulos, sendo que vários deles são dotados de subdivisões, partículas, como no tratado anterior. Mascardi procura "fornecer ao historiador seu ensinamento mais próprio", no primeiro capítulo, estabelecendo a conveniência da história com a poesia e com a oratória, e o modo mais adequado em que pode a história amplificar-se e comover os afetos ${ }^{120}$.

Nesse sentido, exemplifica a prescrição com um uso de amplificação na história, explicando que o fim da amplificatio é fazer do discurso histórico um discurso patético. Ensina, assim, a necessidade dessa técnica elocutiva para a comoção dos afetos e o decoro de sua utilização, prescrevendo dois instrumentos oratórios principais e mais eficazes para tal efeito. Um, o prazer. Outro, o ensinamento:

(...) Diz então Strada, que a amplificação, e a comoção dos afetos, como virtudes próprias do orador, querem pelo historiador em tudo interferir : e não sei quando é verdadeira esta regra, quando geralmente, e sem nenhuma exceção se entenda. A amplificação para dizer a verdade, e a comoção das paixões são dois dos principais, e mais eficazes instrumentos, que tem a arte oratória entre os seus adereços $(. . .)^{121}$.

Diferencia poesia, história e oratória a partir da distinção do modo de dispor dos discursos, não apenas na elocução e no caráter diferenciados nos usos dos gêneros. A maior diferença reside, no entanto, mais no próprio corpo da história que na matéria de que trata, pontua o preceptista ${ }^{122}$ :

(...) Quem destes melhor opõe-se, e de quem fosse a resolução mais louvável, não consigo decidir: sei bem que, segundo Túlio, é ofício do orador perfeito compor a história que ensina, e isto deveria elevar o ânimo como Plínio: sei que Quntiliano falando de história disse est enim proxima poetis, e quadam modo carmen solutum; e isto moveu Agatia. Atingido um e 
outro escritor a autoridade de mestres maiores da arte, me fez resolver sutilmente a semelhança e a diferença entre poesia, oratória e história, porque deste meu trabalho virá certamente o sentimento de um, e de outro; e o que mais importa, o modo de regularmente ordenar, não somente a elocução, e o caráter; mas a parte ainda maior de todo o corpo da história, que a forma mais imediata, que a matéria considerada $(. . .)^{123}$.

Segundo o genovês, a amplificação e a comoção dos afetos têm decoro próprio também na historiografia. Uma história deve apresentar as matérias de modo a interferir no ânimo, narrando-se com vivacidade, vigor e rigor dos acidentes e suas verdades, segundo as circunstâncias particulares, a fim de que o leitor não repugne nada, comovendo-se com a verdade histórica. A amplificação é representada, ainda, na preceptiva mascardina, com a tópica da facúndia, que é tópica motora da poética de Urbano VIII, sinônimo de eloqüência. Define, assim, a amplificação como ponderação:

(...) Paralelamente o historiador procurando, segundo sua obrigação, representar exatamente, mais vivamente as matérias, que narra, procura que no ânimo dos leitores se afete qual são: onde sua primeira finalidade é a de exprimir a concretude dos acidentes, e a de adequá-los com as palavras; as quais porque segundo a diverdidade das suas circunstâncias, quando eficazmente narradas, provoca em quem lê diversos afetos, não repugna a candura, e a verdade do historiador, que tal caso sejam comovidos os ânimos de suas narrações porque isto vem a ser efeito da matéria narrada; por sua culpa resta em parte alguma ofensa à verdade. E este discurso à amplificação também se possa aplicar: porque no orador altera o fato, no historiador o representa: então aí levanta a coisa pequena, e abaixa a grande com a facúndia, que em um, e em outro pontualmente descreve, e iguala com a palavra; onde se na doutrina da eloqüência exageração se chama, no conselho da história ponderação chamar-se-á (...) $)^{124}$.

O capítulo segundo do quinto tratado, "Do modo de formar o discurso, ou de o dispor e o recitar com a conveniência da história ' $\&$ c.' (sic)", divide-se em três partículas. Na primeira partícula, aconselha juízo e arte para a história:

(...) Mas antes de avançar muito dentro na matéria é necessário, que eu volte a pena ao bom compositor de história, e da importância da sua carga o ad- 
moeste. Se alguma parte das coisas desse nobre trabalho deve ser manejada com juízo, e com arte, a textura dos boatos singular diligência requer $(. . .)^{125}$.

$\mathrm{Na}$ segunda partícula, autorizando-se em Luciano de Samósata, recomenda que o historiador conheça os três gêneros retóricos em separado, para perceber, primeiro, como um e outro se reduzem, definindo-se específicos. Somente depois é que poderia misturá-los ${ }^{126}$ :

(...) aqueles ao compor história preparam-se; isto é, que o bom historiador, se quer sustentar suas partes como $\mathrm{Na}$ terceira partícula, recomenda o uso de um estilo que comova de modo breve, mas eficaz, vigoroso e arrebatador ${ }^{127}$.

O capítulo terceiro do quinto tratado, "Do elogio e da censura”, ou seja, do encômio e do vitupério, prescreve ser "obrigação do historiador elogiar de modo tênue, temperado, em estilo médio": “(...) não louvar somente, e vituperar pode o escritor de história, mas por obrigação de ofício ao louvar, e ao vituperar seja estritamente mantida (...)"128.

Mascardi prescreve o encômio próprio de uma história. Para o preceptista, o ponto mais alto da variante epidítica encomiástica é o elogio fúnebre, pois funde vida, subgênero histórico, e panegírico, subgênero demonstrativo-deliberativo. Nesse sentido, o ensino e deleite seriam absolutamente complexos e completos, pois a utilidade se direcionaria para o bom uso da vida e da morte, ensinando não só a viver bem, mas a morrer bem:

convém, deve perfeitamente saber Retórica, para conhecer bem os gêneros, um separado de outro, e depois como de um ao outro se reduz; a fé dos argumentos proporciona a cada um, os estados das questóes; o modo de manejar os entendimentos para adquirir a credibilidade dos ouvintes; o modo de amplificar suas razôes, e de diminuir aquelas dos adversários (... $)^{129}$.

(...) O hábito do louvor após a morte dos homens valorosos com públicas orações nos funerais não é só glorioso por aqueles que morreram, que não seja muito proveitoso para os outros, os que continuam vivos. Isto porque as cinzas indiferentes dos ínclitos heróis não tem prurido de vaidade, que as torne desejáveis de lisonjas; mas a debilidade dos pósteros tem bem necessidade de ensinamentos, e do exemplo, que o valorizam ao caminho da virtude $(. . .)^{130}$. 
Ensina que o encômio na poesia e na história é disposto também de modo distinto. Ou seja, na poesia é um todo encomiástico, uma totalidade, em que a união das partes faz o elogio indissolúvel do corpo do poema. Por outro lado, o encômio histórico é feito de divisões, sendo mais analítico, mais preciso e matemático, pois a narração demonstrativa exige divisóes de partes: “(...) O doutíssimo Pontano no diálogo chamado Attio Sincero, no qual a poesia no conjunto e a história se divisa, para algum moderno, que o ofício do orador ao historiador factualmente se torne comum, que entre um e outro trabalho não se reconheça divergência (...)"131.

Por outro lado, o quarto capítulo do quinto tratado se divide em duas partículas ("Da matéria do homem valente reputar-se comum ao historiador, e ao poeta, e especialmente da ordem ou da disposição" e "É estabelecido não ser a ordem perturbada, nem confusa, nem atrapalhada, própria do poeta, mas comum ao orador e ao historiador") ${ }^{132}$, cujo propósito é o de discorrer sobre "a maneira de o homem valente reputar-se comum ao historiador, e ao poeta, e especialmente da ordem"133. Discute, pois, a dispositio retórica particularizada no uso da história.

Na partícula primeira, Mascardi autoriza suas doutrinas na citação das "Proposiçôes" (a primeira, a segunda, a terceira e a quarta proposições) de Castelvetro ${ }^{134}$, ao tratar da correspondência da poesia com a história, refutando-a. Basicamente, o preceptista discorda de que a poesia e a história sejam coisas conjuntas e que, antes de ajuizar bem o poema, é necessária a história para formá-los, poema e juízo. Segundo Mascardi, isso nega sua tese de que a história é arte liberal, necessária e específica, pois Castelvetro prescreveria a história na prescrição da Arte Poética, tal qual Aristóteles, interesse principal de seu comentário:

(...) Primeira Proposição de Castelvetro. Não pode haver perfeita, e conveniente notícia da poesia pela arte poética, se antes não houver notícia completa da arte histórica. Prova-se dele a proporção; porque antes da natureza vem a verdade, e a coisa representada, que a verossimilhança, e a coisa que representa; sendo que estas daquelas dependem (...). Segunda Proposição. 'História é narração segundo a verdade das ações humanas memoráveis acontecidas; e poesia é narração segundo a verossimilhança das ações humanas possíveis de acontecer', portanto em primeiro lugar se deve conhecer a história, e depois a poesia. Terceira Proposição. A história é coisa 
representada, e a poesia é coisa que representa, sendo assim, a cognição da história deve preceder a cognição da poesia. Quarta Proposição. Os ensinamentos para bem compor uma história não são em sua maior parte próprios da história, mas comuns à história, e à poesia: portanto prescrita a arte histórica, permanece acima da arte poética. Pressupõe finalmente Castelvetro que a arte da história não seja composta, e da maneira tida por Luciano, por Trapezuntio, e por Ridolfo Agrícola, em querer compô-la, persuade-se em provar a verdade da doutrina, nós nas quatro proposiçôes recolhidas $(\ldots)^{135}$.

Diferencia, novamente, a verossimilhança da poesia e a verdade da história, distinguindo verossímeis históricos e poéticos:

(...) Por natureza, a verdade precede a verossimilhança: mas a história é narração segundo a verdade, e a poesia segundo a semelhança do verdadeiro: portanto a história vem antes da natureza que da poesia. O silogismo é de quatro termos, porque a verdade na maior proporção, é verdade metafísica, universal, e abstrata; na menor é moral, particular, e concreta, porque a história não narra geralmente a verdade, mas as ações humanas particulares, que verdadeiras são $(. . .)^{136}$.

Outra vez a auctoritas, por meio de quem Agostino Mascardi autoriza-se em seus Cinco Tratados sobre Arte Histórica, é Luciano de Samósata, autor da sátira lida como prescrição historiográfica nos séculos XVII e XVIII, Como se deve escrever a história. Autoriza-se no sentido de prescrever sobre a universalidade da poesia e da particularidade da história, ensinando que "a história não narra geralmente a verdade, mas as ações humanas particulares, que são verdadeiras". Mascardi repõe os modos in ordo naturalis e in media res, ordo artificialis, da história e da poesia, em conformidade com o costume retórico-poético aristotélico-horaciano:

(...) Duas sortes de ordem (...) se distinguem. Uma chamamos natural; a outra artificial (...). A primeira segue a série ou da natureza, ou do tempo; tanto que fazendo-se na narração das coisas desde o começo, sem perturbação das partes, no meio, e no final sucessivamente chega $(. . .)^{137}$.

Na partícula segunda, Mascardi estabelece

não ser perturbada a ordem das matérias, nem confusa, nem atrapalhada a ordem que deva mobilizar o poeta, mas ser comum ao orador e ao historia- 
dor manter essa disposição: (...) Dado que nos poemas se admita a ordem perturbada, não é próprio da poesia, que não a adotemos por sua semelhança o orador, e o historiador, segundo as ocasióes (... $)^{138}$.

O quinto capítulo do quinto tratado, "Da ordem para o compositor da história e da sua transição" "139, divide-se em duas partículas. A primeira, "Da ordem para o compositor da história e de sua mudança" ${ }^{140}$, versa sobre a ordem necessária à história, considerando aspectos de tempo e lugar. Nesse sentido, o preceptista volta a se ocupar das espécies de narrativas históricas, dos subgêneros, com os quais o gênero histórico varia e se dispersa na prescrição sobre diário, crônica, anais, segundo a ordem do tempo, a qual a história deve seguir, seguindo também os seus modelos ${ }^{141}$ :

(...) Dionísio de Halicarnasso (...) diz; que os bons historiadores à ordem ou do tempo, ou dos lugares se atêm (...). Ponho por ora de um lado, as Crônicas, as Efemérides, e as Vidas; já que o nome delas somente ouvido por quem não é vulgar, declara que ser outra ordem não se conserva, senão aquela do tempo (...). Dos Anais se pode dizer o mesmo: porque recebendo o nome dos anos, dos anos ainda é forçoso, que venham regulados (...). A feitura dos Anais é aquela antiga maçante, recordada por Túlio $(\ldots)^{142}$.

A segunda parte do capítulo também é dedicada a definir história e sua mais adequada disposição das matérias. Ressalta-se que Mascardi mobiliza novamente a noção de corpo, da anatomia humana, para metaforizar uma concepção corporativista da política católica ibérico-italiana, ao reafirmar que a história é corpo.

O sexto capítulo do quinto tratado, "Interiormente a que se limita a semelhança entre o poeta e o historiador na frase, na dicção, na locução do discurso" 143 , prossegue no estabelecimento da elocução adequada para a historiografia, discutindo a elocução poética na história, as semelhanças sofísticas entre história e poesia quanto à elocução. Define, assim, o gênero histórico como epidítico, demonstrativo, próprio do panegírico, concluindo que "a elocução da história deve ser próxima da elocução da poesia”. Mascardi prescreve-a próxima, mas não igual:

(...) Se então o discurso histórico é semelhante à sofística; e se este tipo à poética se assemelha, pela regra matemática, 'qua sunt eadem uni tertio eadem inter se', necessariamente conclui-se, a elocução da historia ser vizi- 
nha à fábula da poesia. Esta mesma ilação se tira de quem discorre com princípios propostos por Hermógenes: o qual dividindo aquele que nomeia político gênero de fala, em três conhecidos membros judicial, deliberativo, e demonstrativo; o último com o próprio nome chama panegírico, e depois mais particularmente Platônico, porque sobre todos os escritores singularmente excelentes sobre Platão naquele tipo de raciocínio; como o mesmo Hermógenes afirma. A esta subclasse não somente a poesia, mas também a história; como daquela delicadeza dos ornatos $(. . .)^{144}$.

O sétimo capítulo do quinto tratado, "Da descriçãa" ${ }^{145}$, estabelece regras para a descrição de acordo com a finalidade do gênero ao qual o discurso pertence. Como uma espécie de decoro descritivo do gênero histórico, Mascardi prescreve cinco regras para o uso da descrição, exemplificando-os didaticamente, após definir a descrição como técnica da evidência, devendo ser útil ao leitor: “(...) O historiador a quem é proposto a utilidade dos leitores (...) usa as descrições sempre que necessárias (...) para maior clareza de suas narrações (...)"146.

A primeira regra manda descrever com exatidão: “(...) faz que o historiador descreva com exatidão as coisas (...), esta será a primeira regra" ${ }^{147}$. A segunda, com importância, elegância e ornamentação moderada:

(...) Como ensina Aristóteles; em solo firme fabricar-se as descrições a seu modo, adornando-a com acidentes, que a possamos deixar ao mesmo tempo mais maravilhosa, e crível (...). Seja esta, então, a segunda regra do historiador; nas descrições não deve por diminuição de força afastar-se da verdade, ao menos nas partes substanciais, e importantes $(. . .)^{148}$.

A terceira regra prescreve a obrigatoriedade de se conhecer a matéria que se vai descrever: “(...) Como terceira regra o entender inteiramente bem a matéria sobre a qual a descrição se atém (...)"149.

A quarta, por sua vez, entender pontualmente, a matéria: “(...) Tanto que para não errar (...) é preciso ao escritor entender pontualmente aquilo que descreve (...)" ${ }^{150}$.

A quinta e última regra para o bom uso da descrição em história é o ensinamento que se extrai daquilo que se torna visto:

(...) Porém é verdade (e seja a quinta regra) que tratando o escritor de matéria afastada da vulgaridade, e que tudo debaixo dos olhos da multidão 
não pode ruir; ou em coisa nova, e incógnita, não deve mais crer de ser minucioso o bastante em descrever-lhe; porque nesse caso, ele é mestre, que simplesmente não narra, mas ensina os leitores $(. . .)^{151}$.

O oitavo capítulo do quinto tratado, "Ethos elocutivo proporcional à história e da maneira estendida" ${ }^{152}$, divide-se em quatro partículas. A partícula primeira intitula-se "Caráter maior próprio da história e porquê"153. Indica cautela no uso desse caráter e prescreve-o "conveniente à história não o sublime, mas o medíocre, o modo panegírico":

(...) como afirma (...) Hermógenes: bem se vê, que o caráter conveniente à história será aquele que resulta do confronto das formas destinadas à grandeza do dizer, e por nós Maior é chamado (...). Compreendeu isto otimamente Hermógenes, (...), o qual querendo que o caráter panegírico, isto é, [seja] aquele que manuseia o historiador $(. . .)^{154}$.

A partícula segunda discorre sobre "o falar dialético", sobre "a tessitura conveniente à história ${ }^{155}$ :

(...) Mas não devo aqui tomar a defesa da eloqüência traída. (...) De propósito os estudos da eloqüência cultivam, e venho mais de perto buscar qual seja o enunciado conveniente à história (...). Túlio repõe a dicção histórica em um termo, que nem se aproxima da estreiteza do falar dialético, nem busque a acrimônia, e a veemência da oratória; mas suavemente copiosa, una à abundância, pela qual se afasta do dialético, o prazer, ou como se diz com palavra mais latina, mas mais significante, a leniência, que a distingue da aspereza, e da veemência do orador $(. . .)^{156}$.

A partícula terceira ocupa-se em considerar os quatro "vícios da forma estendida" 157 , nomeando-os obscuridade, desligamento, desamarração e dureza, examinando mais particularmente a obscuridade com a doutrina de Quintiliano e de Aristóteles.

A partícula quarta prescreve o uso ou não uso da brevidade, brevitas $^{158}$. Mascardi, em resumo, prescreve o uso do modo proporcional para uma história.

O nono e último capítulo não só do quinto tratado, mas da preceptiva de Agostino Mascardi, "Do uso da sentença e do epifonema e da comparação" ${ }^{159}$, propõe a interpenetração das máximas políticas, das máximas sentenciosas, dos epifonemas na história, cujo efeito buscado é o de provocar exclamação, afetando o receptor ao final de uma narração. 
Mimeticamente dispostas as matérias da Arte Histórica, em relação às prescriçôes, fecham-se como ensinamentos, cuja adequação de doutrina e ação é excelente e também exclamativa, por encerrar justamente com um tipo de matéria própria não só em relação ao uso da tópica, mas com a matéria que prescreve o efeito de exclamação que se deseja do leitor ao término do texto, devendo portanto comover e mover leitores de história coevos da Arte.

\section{Gráfica Temperada}

Os preceitos acima descritos e comentados são, basicamente, categorias técnico-retóricas relativas à narrativa no uso do gênero histórico, como: amplificação, descrição, digressão, encômio, exemplo etc; e categorias relativas ao gênero histórico propriamente dito, como: anais, comentário, décadas, diário, efemérides e vidas. As seis últimas categorias podem ser entendidas como subgêneros históricos. Todas essas categorias, no entanto, permitem definir o gênero histórico seiscentista como um discurso fabricado pela arte, em conformidade ao conceito retórico aristotélico de gênero em suas retomadas latinas, retomadas costumeiramente chamadas medievais e em retomadas quinhentistas e seiscentistas.

Moralizada pela doutrina católica contrareformista, como a da Luz Natural da Graça, a história seiscentista é doutrinada, temperadamente, no Dell'Arte Historica pelo engenho e pelo juízo, porque em respeito às prescrições epidíticas ou demonstrativas de variantes encomiásticas, cujas funções didáticas e deleitadoras são desempenhadas pelas técnicas demonstrativo-deliberativas de tirar ou extrair do natural (do testemunho) e pôr às vistas (aos olhos do destinatário). Sua finalidade é a de fazer ver para saber fazer, ensinar a fazer, comovendo e movendo o leitor/ouvinte/espectador.

Sob a égide de Marte e sob a efígie de Mercúrio, o gênero histórico ibérico-italiano é feito como gravura bélica e facunda, ou seja, forte e vigoroso. Moralizado de modo católico, o gênero figura o desenho arrazoado por hérois e, sobre eles, suas ações e seus lugares, a seus pares institucionais. Os deuses antigos da guerra e da eloqüência não são retomados com ethos pagão, mas católico. A pena dessa escrita não é de Marte, uma vez que, na escrita de guerra, o pincel é de Mercúrio e a espada é de Marte, 
não a tinta da eloqüência; porém, nos usos seiscentistas do gênero histórico, fundem-se retoricamente espada e pincel, sangue e tinta em conveniente quiasma.

Colhe-se da doutrina seiscentista ibérico-italiana sobre arte histórica que a história é, no século XVII, um gênero superior à poesia, cuja tópica principal do discurso é a guerra. A diferença entre poesia e história é retomada pela Arte Histórica pela dicotomia verdade da história/fábula da poesia e seus modos miméticos das disposiçôes in ordo naturalis (história) $\mathrm{X}$ ordo artificialis (poesia), distinção cara a Aristóteles e a Horácio, mas de valoração diferente no século XVII. Aristóteles pensa a superioridade da poesia pela universalidade dela em oposição ao outro gênero, enquanto letrados, como Mascardi, pensam-na inversamente. Não obstante, essa verdade seiscentista deve relacionar-se com príncipes e diplomatas, pois a fé histórica, que é fides rhetorica, fides estilística, que é fé retórica, é possibilitada pelos opináveis dos tipos superiores (endoxa) que se submetem à fé divina, ou seja, verdade moralizada, mediada, iluminada por Deus e suas autoridades. A história seiscentista deve, portanto, ser feita sacra, civil, urbana e de costume latino, principalmente. Doutrina-se e mobiliza-se, então, o gênero histórico em círculos eclesiásticos, acadêmicos e militares movidos por polêmicas e disputas pela hegemonia de estilos e de poderes das representaçóes.

A finalidade primordial da arte em questão é polir o historiador para a escrita de uma boa história, que seja bem disposta e bem formada e verse sobre os acidentes humanos dignos de memória (dignitas). A história é, pois, uma seqüência de narraçôes harmoniosamente entrelaçadas que deve dizer a verdade por meio de um conjunto completo e não confuso, de boa ordem e com boa disposição. Conceitua-se a verdade, no século XVII, como óculos da história, cuja função visual é notória, como a metáfora que a realiza, portanto verdade metaforizada. Nesse sentido, autorizados principalmente por Cícero, letrados e artífices têm a verdade como referência para formar e ler a história, para fazê-la vista e para vê-la, pelas lentes desses óculos. Nesse sentido, a história deve ser lida segundo os costumes e segundo seu modo prolongado de ser composta, ou seja, segundo o decoro. 
Entretanto, nem tudo é história, nem crônica, segundo a preceptiva estudada. A rigor, o gênero tem como "hiperônimo" o conceito "história" e como "quase sinônimos" tem subgêneros como os anais, os comentários, os diários e as vidas. Em termos de discurso, comentários e diários são englobados pela categoria "efemérides", uma vez que dizem respeito à narração das coisas no tempo de um dia, daí as datas, os jornais e os calendários. O jornal é tido, no século XVII, como efeméride mercantil, enquanto que os diários, como comentários dos dias; os anais, por sua vez, são comentários dos anos. A história é relato de eventos vistos e interpretados pelo escritor, pela persona testemunhal figurada pelo discurso. Os anais são a narração de acontecimentos do tempo, cuja escrita deve refletir o passado do ano. A crônica é a história dos tempos. As vidas, por sua vez, relatam ações de homens santos e ou heróis, cuja função é regular o costume, sendo prescritas como tendo que seguir a vida dos homens virtuosos do nascimento à morte.

O narrador do gênero histórico é do tipo narrador não autor dos eventos, mas juiz deles. Letrados exercitam-se imitando, na escrita, a natureza como ela foi fabricada, cuja gráfica ${ }^{160}$ temperada se faz como farmácia, como topografia e como cosmética ${ }^{161}$. Fabricação da fabricação que deve mover o leitor/ouvinte/espectador no mínimo por três modos ou por três tipos de efeitos que levam aos afetos pretendidos: por adulação, por medo ou por amor. Adulação e medo dos grandes encenam o ânimo servil decoroso para o uso do gênero, uma vez que o motor para se escrever história, no século XVII, é formar no ânimo de quem lê o efeito da virtude, pela imitação de exemplos de heróis, varões ilustres, guardando-os e perpetuando-os na memória, cuja função é primordial na arte estudada. $\mathrm{O}$ amor redunda nos lugares de pessoa aplicados pelos (e aos) tipos superiores, tidos como bons, por isso belos e úteis no elogio da pátria, da família, dos amigos etc.

O discurso do gênero em questão pede um tipo de elocução que se afaste do ordinário, mas sem perda dos nexos, nem das correspondências entre as partes em relação ao todo, portanto proporcional, simétrico. Assim, o estilo ou o decoro elocutivo recomendado para esse tipo de prática é aquele que comove breve e eficazmente, pois vigoroso e arrebatador. Por sua vez, o encômio, no (e do) gênero deve ser construído de modo tênue, 
temperado, em estilo médio, que na história se divide de modo diferente do que na poesia, pois na primeira é mais dividido, mais analítico que na segunda, conforme o conceito de gênero demonstrativo-deliberativo aristotélico-escolástico. Esse estilo, contudo, assemelha-se ao estilo sofístico, porque argumentativo e de tendência ao consenso, ou que tende a fabricar o consenso das opiniōes e dos juízos. A medida justa, proporcional, entre engenho e juízo, ensinamento e deleite, propõe o estilo do gênero como engenhosamente judicioso, temperado, alto e grave, e não médio ou humilde, pois como afirma Tesauro, autorizando-se em Aristóteles, o estilo histórico é o peregrino ${ }^{162}$. Peregrino é o mesmo que "estranho" ou "singular", avesso ao medíocre e ao rasteiro. Não que não haja humildade na relação de interlocução no gênero histórico, mas é modéstia afetada, no caso católico, posição inferior artificiosamente pensada, cujo fim é o de valorizar a hierarquia e reafirmar a produção do bem e do belo na construção do encômio dirigido a heróis e figuras tidas como ilustres, valentes, dignas de nota e memória, portanto exemplares e modelares.

Entretanto, como prosa, o gênero histórico conforma-se também com o conceito de amplificação, portanto em estilo alto, grave, que não se confunde com o estilo médio temperado do encômio que o gênero demanda e mobiliza. A amplificação, ao lado da descrição e da digressão, faz com que se comovam os afetos dos leitores/ouvintes/espectadores, pois fabricadores do pathos. Ao amplificar o discurso, pondera-se, representando-se os eventos e não os alterando como ocorre na oratória, por exemplo, mas fazendo-os maravilhosos e de tendência ao sublime. $\mathrm{O}$ uso da categoria "amplificação" permite que a história seja suavemente copiosa, unindo a abundância, o prazer distinto da aspereza, da obscuridade e da dureza que, por ventura, possam desligar as partes do todo. Nesse tipo de discurso, amplifica-se, recorrendo-se à categoria "digressão" que, basicamente, é operada pelo uso, por exemplo, de enumeraçóes e epítetos nas descrições. Nesse sentido, hierarquizam-se as categorias, tendo-se: a amplificação como categoria maior, ou superior, subordinando a digressão, que se confecciona, prioritariamente, pelas descrições. O gênero admite, assim, um uso de digressóes em uma medida 'certa', ou seja, mediano, pois desta maneira o discurso é capaz de provocar na audiência a curiosidade exata e o efeito pretendido que pode iluminar a arte. $\mathrm{O}$ uso de di- 
gressões recomendado é, desse modo, aquele que espalha ou salpica, como tempero, digressões pelo corpo do discurso, interrompendo apenas o necessário e corroborando para a construção do louvável, do belo, do bom e do útil, isto é, contribuindo para a fabricação do encômio que o gênero visa e deve fazer ser visto, porque gênero público do discurso. As digressões necessárias, conforme a doutrina, são as de lugar, de tempo, de instrumentos, de costumes, de formas de governo, das cerimônias, entre outras particularidades; por isso tudo, também, são expedientes historiográficos por excelência e não poéticos, uma vez que se fazem digressões de particularidades, como dito, e não de universais. As descriçōes, por outro lado, subordinadas à amplificação e às digressões, são, no século XVII, chamadas 'pintura de história', como doutrinou Mascardi autorizado por retores antigos, principalmente Quintiliano. Entendidas como argumentos historiográficos são, por exemplo, topografias à imitação da pintura. Como técnica da evidência (do latim evidentia e do grego enargeia), as descriçôes permitem a clareza da narração, devendo ser feitas com exatidão, importância, elegância e ornamentação moderada, para ensino e deleite da audiência, pois tornam mais maravilhosas e críveis as histórias, em virtude de o gênero não ter apenas que narrar as matérias, mas ensinar o leitor a usá-las, tomando-as como suas, isto é, aderindo à argumentação patética figurada.

O que foi demonstrado acima pode definir o gênero histórico seiscentista como um saber gráfico e não como uma positividade romântica que não discrimina variações, nem técnicas retóricas, nem morais, mas 'contextualiza' em 'barroco' anacrônico todos os relatos históricos seiscentistas como crônicas ou como história.

\section{Notas}

${ }^{1} \mathrm{O}$ historiador, poeta, professor de retórica e preceptista de arte histórica e de arte poética, Agostino Mascardi nasceu em Sarzane, província do Estado de Gênova, em 1591 e morreu em 1644. O primeiro biógrafo de Mascardi é, talvez, Mannucci. Cf. MANNUCCI, F. L. La vita e le opere di Agostino Mascardi com appendici di lettere e altri scritti inediti e um saggio bibliografico. In: Atti della Società Ligure di Storia Patria, XLII, 1908, pp. 4 sgg.

${ }^{2}$ Trata-se de Doutrina seiscentista da arte histórica: discurso e pintura das guerras holandesas (1624-1654). Tese de Doutorado apresentada ao Programa de Pós-Graduação em Letras Clássicas e Vernáculas da Faculdade de Filosofia, Letras e Ciências Humanas da 
Universidade de São Paulo. São Paulo, 2005. Esse trabalho teve como orientador o Professor Doutor João Adolfo Hansen e o subsídio da Fundação de Amparo à Pesquisa do Estado de São Paulo (FAPESP), aos quais agradeço. Agradeço também a Sérgio Ferreira Mendes pela revisão da tradução das passagens em italiano.

${ }^{3}$ Cf. MASCARDI, Agostino. Dell'Arte Historica - Tratati Cinque. Roma: Apresso Giacomo Facciotti, 1636.

${ }^{4}$ Op. cit., $1^{\circ}$ Tratado, cap. I, p. 3.

${ }^{5}$ Cf. TESAURO, Emanuele. Il Cannocchiale Aristotélico ossia idea delle argutezze heroiche volgarmente chiamata impresse examinate infonte co' rettorici precetti del divino Aristotele, che comprendono tutta la Retorica e la Poética Elocuzione. Turin: Sinibaldo, 1654.

${ }^{6}$ Cf. HANSEN, João Adolfo. "Juízo e engenho nas preceptivas poéticas do século XVII". In: NASCIMENTO, Evando et OLIVEIRA, Maria Clara Castellóes de. (Orgs.). Literatura e filosofia: diálogos. v. 1. Juiz de Fora/São Paulo, 2004, p. 98.

${ }^{7}$ Idem ibidem, p. 102. Como propõe Hansen, o efeito icástico consiste "na união do entendimento com a fantasia e implica a proporção adequada como meio-termo de dialética e ornamento: é, genericamente, o da representação entendida como icástica ou proporcionada", pois mantém "a unidade entre as coisas da invenção e as palavras da elocução". Com isso, tem-se "'fantasia com juízo', a fantasia recorre ao juízo e, guiada por ele, expóe as imagens que apreendeu por meio dos sentidos. Também pela união ou pela separação dessas imagens, confere-se ser a forma a novas imagens, que não existiam antes. O que se faz, contudo, subordinando-se a fantasia ao juízo, como controle ou regramento da figuração". Idem ibidem, pp. 111-112.

${ }^{8}$ Cf. MASCARDI. Op. cit, partícula VI do 4o Tratado, pp. 399-407.

${ }^{9}$ Cf. op. cit, p. 103.

${ }^{10}$ Idem ibidem, pp. 127-128.

${ }^{11}$ Cf. Op. cit, pp. $7-8$.

${ }^{12}$ Carta endereçada ao $3^{\circ}$ Conde da ericeira, D. Luís de Meneses datada de 1688.

${ }^{13}$ Cf. FUMAROLI, Marc. Op.cit., pp. 135-136.

${ }^{14}$ Cf. BERTELLI, Sergio. Rebeldes, libertinos y ortodoxos en el barroco. Trad. Marco-Aurelio Galmarini. Tard. Latim Privat Rodríguez Sadurní. Barcelona: Ediciones Península, 1984 , p. 69.

${ }^{15}$ Essa recepção encontra-se ao final do volume, logo após o índice das matérias.

${ }^{16}$ Cf. BERTELLI, Sergio. Op. cit., p. 36.

${ }^{17}$ Cf. NICERONE. Op. cit Ainda no século XVIII vai circular outra recepção de Mascardi, porém já em chave iluminista. Cf. NAPIONE, Gian Francesco Galeani. Prefazione. In: Saggio sopra l'Arte storica. Torino, 1773. Cito: “(...) Foi Agostino Mascardi, que no século passado se ocupou dessa arte amplamente, quem disse, haver no ânimo dos observadores preceitos para se pôr em prática em uma história determinada (...)".

${ }^{18}$ Cf. BARTOLI, Adolfo. (1859); cf. ediçôes das respectivas casas Mucchi e Rosa di Gericó (1994).

TOPOI, v. 7, n. 13, jul.-dez. 2006, pp. 331-378. 
${ }^{19}$ Cf. TIRABOSCHI, Girolamo. Storia della Letteratura Italiana. Venezia: Typ. Molinari, 1824, pp 591-593; BAYLE. Dict, 3a ed. t. 3, 1720, p. 1953. Cf. Enciclopedia Italiana di Scienze, Lettere ed Arti. Roma: Instituto della Enciclopedia Italiana fondata da Giovanni Treccani, 1949; FLORA, Francesco. Il Cinquecento (parte 2a) - Il Seicento - Il Settecento. In:Storia della Letteratura Italiana. v. III. Nouva Edizione riveduta e ampliata. Arnaldo Mondadori Editore, 1956.

${ }^{20}$ Cf. SANTOS, Magnólia Costa. Nicolas Poussin: Idéia da Paisagem. Tese de Doutorado apresentada ao Programa de Pós-Graduação em Filosofia da Faculdade de Filosofia, Letras e Ciências Humanas da Universidade de São Paulo. São Paulo, 1997, pp. 192/215. ${ }^{21}$ Cf. BETTARINI, Masca. Agostino Mascardi scrittore e teórico della storiografia nel Seicento. Verona: Quaderni di 'Nova Historia', 1953.

${ }^{22}$ Cf. MANUCCI, F. L. Op. cit.

${ }^{23}$ Cf. BERTELLI, Sergio. Op. cit., p. 129.

${ }^{24}$ Cf. BELLINI, Eraldo. Agostino Mascardi fra "ars poetica" e "ars historica". In: Studi setenteschi, v. XXXII, 1991.

${ }^{25}$ Cf. MASCARDI, Op. cit, pp. 1-22.

26 “(...) che gl'isegnamenti indirizzati alla prattica; per agevolar à me stesso, \& à qualunque fosse vago di questi studi, il modo di ben comporre un' historia, sotto l' esempio de' grandi antichi (...)". Op. cit., p. 1-2.

27 “(...) la materia, intorno à cui fatica ne' suoi racconti l'historico, havessi poscia accennato il modo di ben disporla, e formarla (...)”. Idem ibidem, p. 2. Lembro que todas as citaçôes em italiano seguem a grafia seiscentista encontrada no volume consultado.

28 “(...) diffinisce una catena di narrationi gentilmente intrecciate, può peraventura dir vero, non per tanto rimane mancante insieme, e confuso: perche molte narrationi da' favoleggiatori con bell' arte s' intercciano, che nondimeno historia veramente non sono (...)". Idem ibidem, p. 4.

${ }^{29}$ Idem ibidem, pp. 2-4; 7.

${ }^{30}$ Idem ibidem, pp. 23-42.

${ }^{31}$ Idem ibidem, p. 30.

32 “(...) l'ufficio di componitor dell' historia, e solito à commettersi à personaggi d' eccellenti qualità, e per sourane dignità meritevoli di riverenza (...)”. Idem ibidem.

${ }^{33}$ Idem ibidem, pp. 43-66.

34 “(...) Quindi nacquero l’ Effemeridi, ò vogliam dire i Diarij, gli Annali, le Cronache, $\hat{\imath}$ Commentarij, e le Vite, che tutte nomar historie (...), perche tutte s' indirizzano ad eternar le memorie degli avenimenti passati, per ammaestramento della posterità (...)”. Op. cit., p. 43.

${ }^{35}$ Idem ibidem, p. 44.

${ }^{36}$ Idem ibidem, p. 47.

37 “(...) che l' Effemeridi, e nominatamente di quei di Cesare, dice (favellando della fraude, con che i Germani sotto la tregua assalito l' havevano (...)". Idem ibidem, p. 54. 
${ }^{38}$ Idem ibidem.

${ }^{39}$ Idem ibidem, p. 58.

${ }^{40}$ Idem ibidem, p. 59.

41 “(...) l' historia essere um racconto degli accidenti veduti dallo scrittore, l' annale una narratione d' avvenimenti da' nostri tempi, e dalla nostra ricordanza lontani, come non riceuuta, nè dall' uso dè buoni, nè da ragione, che la sostenti, s'è da noi volontariamente lasciata; parendoci, che dal modo delo scrivere ristretto al giro dell' anno, e da qualche parte della materia più minuta, possano gli annali bastevolmente distinguirsi dall' historia (...). Delle cronache poi diremo solo, di lor natura altro non essere; che l'historia de' tempi (...). Rimane hora, che delle Vite alcuna cosa s' osservi, e sarebbe materia non solamente dilettosa, mà necessaria (...) che l'attioni d' homini santi raccontano: le quali bene spesso, quanto con la maraviglia douuta alla virtù transcendente i confini dell' humana debolezza, rapirebbono gli occhi, e l'animo de leggenti; tanto per l' imperitia, ò per la verbosità di chi fabrica (...)". Op. cit., pp. 61-63.

${ }^{42}$ Idem ibidem, p. 64.

43 “(...) Sappia primeiramente chi scrive una vita, (...), per regolar il costume (...), si può dalle vite degli huomini guerniti d' eminente virtù (...), conducendo il suo personaggio dalla prima nascita fino all' ultima caduta (...)". Idem ibidem, p. 64.

${ }^{44}$ Idem ibidem, pp. 66-92.

${ }^{45}$ Idem ibidem, p. 69-70.

${ }^{46}$ Idem ibidem, p. 87-88.

47 “(...) Ne la Geografia di sua nature è argomento d' historia, tutto che tale esser possa per acidenti, perche se nella descrittione de' luoghi, come porta il nome, s' impiega; (...) non fai mai, che giustamente narratione historica (...). La Geografia (...) è un' imitatione d' una pittura di tutto il corpo della terra conosciuta (...)". Idem ibidem, pp. 87-88.

${ }^{48}$ Idem ibidem, pp. 92-105.

${ }^{49}$ Idem ibidem, p. 103.

50 “(...) Rimane hora à giustificar il titolo del libro, per disaminar se l' historia cada sotto $i$ precetti dell' arte, cioè à dire se si possano prescriver regole certe, com l' indirizzo delle quali altri componga artificiosamente l' historia (...). (...) scrivo dell' arte historica, fu mossa parimente à Quintiliano, quando scriveva dell' arte rettorica (...)". Idem ibidem, p. 103.

${ }^{51}$ Idem ibidem, pp. 108-116.

52 Idem ibidem, p. 109.

${ }^{53}$ Idem ibidem, pp. 110-111.

54 “(...) Si come il fondamento della fede publica nelle cose civili, dipende dalla penna degli scritori, così dee studarsi l' historico, che la verità nelle sue carte habbia luogo incontaminate, e sincero (...)". Idem ibidem, p. 108.

${ }^{55}$ Idem ibidem, pp. 117-129. 
56 “(...) La fede, che si presta all' historie è fede humana, cioè a dire sempre congiunta col' l dubbio, poiche nell' essenza non s' allonta dall opinione. E dunque ingiurioso il lettore, se chiede dall' historico la certezza infalibile, appoggiata all' autorità, che non riceva contrasto (...)". Idem ibidem, p.127-128.

57 “(...) alla fede divina la verità tanto indubitata, quanto si si dee alla divinità, che la rivela (...)". Idem ibidem.

58 “(...) d' um huomo savio, e di conosciuta bontà, che mai per eletione non mente (...)". Idem ibidem.

${ }^{59}$ Idem ibidem, pp. 129-142.

${ }^{60}$ Idem ibidem, p. 131.

${ }_{61}$ “....) Questo primo insegnamento, di non contaminar la candidezza della verità con le bugie, è tanto necessario, che secondo il sentimento di Timeo presso Políbio, l'historia perde la sua natura, se perde la verità. Specchio della vita humana è l' historia, ma se lo specchio non rende l' imagine del volto somigliante all' opposto esemplare, ne può nomarsi specchio, ne la figura, che rappresenta, per imagine si ricosce. Polignoto, e Dionigi furono di pinttori eccelenti, mà il primo formava con l' arte i ritratti molto piu belli, che la natura non haveva fabricati (...); il secondo poneva tutto l' ingegno in trapportar un volto nelle sue tele. Polignoto a mio parere è simbolo del poeta (...). Dionigi è l' historico, che prende religiosamente tramanda alla posterità la semplice sembianza del vero (...)”. op. Cit., p. 131-132.

${ }^{62}$ Idem ibidem.

${ }^{63}$ Idem ibidem, pp. 142-158.

${ }^{64}$ Idem ibidem, pp. 151-153.

65 “(...) Questo verosimile, che intorno à materia falsa s' aggira, falso anch' egli parimente s' appella (...) Hor questo verosimile, che si conforma co' l fatto, s' appella vero (...)". Idem ibidem, p. 152.

66 “(...) Finge Virgilio per cagion d' esempio, Didone Reina di Cartagine innamorata d' Enea, ch' abbandonata, e tradita furiosamente s' uccide. Il fatto è tutto falso, (...) rattiene com tuttociò la somiglianza del vero (...). All' incontro Scipione, (...) vede una bellissima donzella fra la turba de prigionieri, e poteva (...) usar del fruto del vittoria recandola a suoi piaceri, egli non tanto (...) con le leggi della ragione conserva inviolata la donzella (...). Il fatto è vero mà parimente è verisimile (...)". Idem ibidem, p. 151-152.

${ }^{67}$ Idem ibidem.

${ }^{68}$ Idem ibidem, pp. 159-169.

${ }^{69}$ Idem ibidem, pp. 170-188.

${ }^{70}$ Idem ibidem, p. 171.

71 “(...) si scrive (historia) (...) per formar nell ' animo di chi legge il simolacro della virtù, imitato dagli esempi di tanti incliti Eroi (...)". Idem ibidem.

72 “(...) che però filosofia d' exempi appellò Dionigi Alicarnasseo l' historia (...)”. Idem ibidem.

${ }^{73}$ Idem ibidem pp. 180-189. 
${ }^{74}$ Idem ibidem, pp. 189-206.

75 “(...) La prima sia l' adulatione (...) specialmente de' Grandi, con cui ogni spirito, ogni bellezza del' historica verità si contamina, e si corrompe (...)”. “(...) Perché l'adulatione, e la paura sono quasi parti gemelli d' un animo (...) servile (...)”. "(...) Conchiudo dunque con Polibio, che essere amorevole della patria, degli amici, e de parenti è parte di sua natura d' huomo da bene (...)". Idem ibidem, pp. 190/196/206.

${ }^{76}$ Idem ibidem, pp. 207-218.

77 Talvez esse seja um capítulo fundamental para o debate anti-sofista referido no início deste ensaio.

78 “(...) E così debole l' avvedimento degli huomini, che non di rado nel giudicare, viene ingannato dalle apparenze, con manifesta ingiuria dell' intelecto ben regolato, perché essendo lubrico il confin delle cose, la somiglianza talhora fa frode alla diligenza di chi vorrebbe discernere pienamente il vero. Discorre di ciò dottamente Platone, \& apporta la diferenza, che ripor si dee, per non errare, fra le arti nó meno alla coltura dell' animo, che alla cura del corpo destinate, e quelle che com falsa apparenza imitandole le corrompono (...)". MASCARDI. Op. cit, p. 208.

${ }^{79}$ Idem ibidem, pp. 219-327.

${ }^{80}$ Idem ibidem, p. 219.

${ }^{81}$ Idem ibidem, p. 222.

${ }^{82}$ Idem ibidem, p. 236.

${ }^{83}$ Idem ibidem, pp. 220-239.

84 “(...) Strani, \& impensati avvenimenti partorisce la guerra; i quali, e per la novità maravigliosi, e per la frequenza innumerabili, e per l'atrocità compassione voli, diero occasione all' antico proverbio de' Greci 'Bellum omnium pater'. Ma niun parto più mostruoso da lei si propaga, che l' infinita figliolanza degli historici, ch' in un solo portato esce alla luce del mondo (...)”. Idem ibidem, p. 221.

85 “(...) Scrive l' historie colui, che non ha per avventura mai letto altro historico, che Palmerino d'Oliva, e Florestano; che non ha studio d'eloquenza, \& esercitio di stile; che non ha contratto habito alcuno di prudenza civile; che non fa che cosa sia elocutione; che non conosce l'ordine nelle scritture; che non intende la corrispondenza delle parti in tutto il corpo dell' historia; in somma, che per prurito d' ingegno, e forse anche per abbondanza d'otio, abbraccia, a cagione diporto, quel che non si fa bene senza lunghissimo studio da un maturo, e perfeito giudicio (...)”. Idem ibidem, p. 222.

86 “(...) Se meglio possa sodisfare al debito di buon' Historico, un Principe, un Capitano, od” altro huomo di stato, che una persona privata, benche guernita di buon giudicio, ò di sufficiente cognitione delle cose del mondo (...)". Idem ibidem, p. 223.

${ }^{87}$ Idem ibidem, pp. 223; 231; 236; 238.

88 “(...) Da' Principe, da' Capitani, e dagli huomini di stato bramerei l' effemeridi, o vogliam chiamrgli i diarij, che somministrasse opportunamente la selva all' historico (...)”. Idem ibidem, p. 236. 
${ }^{89}$ Idem ibidem, pp. 240-260.

90 “(...) Quattro erano, per quello c’ hò saputo osservare, i grandi della buona educatione, per via degli esempi; e quattro gli strumenti de quali si valevano i nostri maggiori. La Pittura, la Poesia, l' Historia, e la Filosofia. Della Pittura su detto saviamente, c' haveva il popolo per maestro; ma si può di lei dire all' incontro, ch' ella è maestra del popolo; poiche gli huomini vulgari, che sono mal guerniti d' intendimento, e di lettere, \& i fanciulli, ch' in questa parte debbono essere annoverati co' l popolo, non hanno altro libro, che la pittura; la quale gli avvenimenti passati co' $i$ colori rappresentando, viene in guisa di muta historia ad insinuar negli animi rozi, per mezo degli occhi, l'esempio del bene, ò del male (...)". Idem ibidem, p. 246.

${ }^{91}$ Idem ibidem, pp. 246-249; 260.

${ }^{92}$ Idem ibidem.

${ }^{93}$ Idem ibidem, pp. 261-282.

${ }^{94}$ Idem ibidem, pp. 262-263.

95 “(...) Impercioche dovendo l' historico, che vado tuttavia formando, ripulirsi all' idea degli scrittori eccellenti, apprendendo più dall' imitation loro, che dagli insegnamenti di chi che sai; non si disdice il prescrivergli il modo da tenersi nel leggerrgli, accioche non vada indarno pellegrinando l' ingegno fuori della via regia, per sentieri dubbiosi, la cui uscita bene spesso non si prevede (...)". Idem ibidem, p. 263.

${ }^{96}$ Idem ibidem, pp. 283-310.

97 “(...) La digressione così nomata in Italia da più eleganti, e prosatori, e poeti, negli idiomi forastieri fortisce diversi nomi, che tutti vogliono richiamarsi ad esamina, per non lasciar pur un ombra di dubbio, che rendesse men chiara la dottrina di questo capitolo. Egressus, ò, egressio su da Latini appellata, como si vede in Quintiliano, \& anche exessus per sentimento di Servio (...)". Idem ibidem, p.284.

98 “(...) può chiamarsi episodio, il che pur consente Polluce nell' onomastico, che lo diffinisce una cosa avventitia, o inserita nell' altra (...), le musiche nelle conversationi, le commedie nelle nozze potran nomarsi episodio; e cosi le noma Plutarco (...)”. Idem ibidem, p. 285.

99 “(...) La digressione oratoria, detta da Quintiliano egressus \& egressio, da Greci (...) si diffinisce, alienae rei, sed ad utilitatem causae pertinentis, extra ordinem excurrens tractatio. Questa benche primamente originata dall'ostentatione degli antichi declamatori, approvata nondimeno à poco à poco dal' uso, discese nelle cause civili, e fu ricevuta ancora ne tribunali, ma parve per un tempo, che più servisse alla pompa degli avocati, che alla necessità dé clienti (...) $e$, considerato (...) che dalle digressioni ricevevan le cause, con sollevar l'animo degli uditori, e del giudice dalla seccaggione della semplice narratione gia stanco; con alcune poche regole su ridotta ad esser giovevolissimo strumento della retorica (...)". Idem ibidem, pp. 288-289.

100 “(...) Supposto tutto ciò, che si è detto, vengo alla materia propria di questo capitolo, $e$ chieggo, se possa l' historico valersi della digressione; giàche, \& al poeta, \& all' oratore, non vien da savi, ne loro copponimenti disdetta. Negano ciò assolutamente alcuni autori moderni, e ter cagione apportano della dottrina, ch' insegnano (...)". “(...) La continuatione delle cose, che in un' ordinato raccôto, quasi con gli occhi si veggono dal lettore, nó consente un importu- 
no interrompimento, da cui divertito l' animo di chi legge, rimanga privo del gusto, \& in gran parte dell' utile, che si può trar dall' historia: e questa prima ragione ha qualche sembianza di verità. La seconda è tanto sciocca, che non ardisco di referila (...)". "(...) Terzo. Non tutte le digressioni, che dagli autori si recevono nell' historia debbono in grado uguale riporsi (...)". Idem ibidem, p. 290/292.

101 “(...) L' historico non solamente contro l' arte non pecca, spargendo di digressioni l' historia; ma tradirebbe la giusta curuiosità del lettore, tralasciando le necessarie; priverebbe de più stimati lumi dell' arte l' opera sua, non formando le lodevoli; come che possa astenersi da quelle, che gli si tollerano; e debbia fuggir l' ultime, che si risiutano (...)". Idem ibidem, pp. 292-293.

102 “(...) Necessarie stimo quelle digressioni, che recano qualque notitia, c' habbia del singolare, e senza la quale molti luoghi dell' historia rimarrebbono male intesi, \& oscuri. In questo numero le descrittioni comprendo de siti, de tempi, degli strumenti, de costumi delle genti, delle forme del governo, delle consuetudini de popoli, delle ceremonie nelle cose sagre, e d'altre particolarità; le quali se non precedono alla narratione del fatto, si trova al buio il lettore, ne può formar concetto bastevole de successi: perche nella testura dell' historia molte cose di passagio s' accennano, le quali se dovessero più largamente dichiararsi in que luoghi, verrebbono ad interromper con tedio il filo della narratione; dove all' incontro si rapportano a quella scorsa, che già s'è fatta, la quale pone gli avvenimenti sotto gli occhi al lettore, come se dipinti, e non raccontati gli rimirasse (...)". Idem ibidem, p. 293.

${ }^{103}$ Idem ibidem, pp. 311-327.

104 “(...) S’ aggiunga à questa prima libertà conceduta allo scrittor dell' historia una seconda licenza, non meno importante della passata, e con lei per natura strettamente congiunta; e fia il dar tal' hora giudicio delle attioni, che cadono nel racconto, '\$ de confiljs significare, quid scriptor probet', disse Cicerone: la cui autorità seguendo il douttissimo Pontano, constituice l' historico in guisa di Giudice, e forse più ampia gli consente la giuridittione di quello, che veramente gli si convenga (...)". Idem ibidem, p. 320.

${ }^{105}$ Idem ibidem, pp. 330-333.

${ }^{106}$ Idem ibidem, pp. 329-407.

${ }^{107}$ A primeira partícula ("No qual se examina a voz latina stilus") vai das páginas 333342; a segunda ("Da voz grega") vai das páginas 343-350; a terceira ("Da elocução e se nela consiste o estilo") vai das páginas 350-361; a quarta (“Três caracteres da fala, e se se fundamentam nessas matérias") vai das páginas 362-383, a quinta ("Se propõe, e se olha uma oposição, e se declara a natureza do ethos, e do estilo por causa diversa do ethos se soluciona") vai das páginas 383-399 e a sexta e última partícula desse capítulo ("Em que coisa consiste o estilo”) vai das páginas 399-407.

108 “(...) Stylus, ò Stilus, comunque si scriva, secondo il sentimento suo naturale, altro non era, che uno strumento da una parte acuto, e dall' altra assai largo, che s' adoprava per segnar nelle tavolette incerate i caratteri, secondo l'uso di que' tempi, che rapportato al nostro secolo, o alla nostra usanza, si direbbe strumento da scrivere (...)". MASCARDI. Op. cit. p. 334.

${ }^{109}$ Idem ibidem, p. 349-350.

TOPOI, v. 7, n. 13, jul.-dez. 2006, pp. 331-378. 
110 “(...) La maggior parte degli autori tanto Greci, quanto Latini dichiarano, il carattere del dire altro non essere, che quelle tre famose maniere di favellare (...), che sono la magnifica, l' humilde, e la temperata, delle quali diviseremo à suo luogo (...). L' elocutione; ̀̀ sia quasi genere applicato alle tre specie da noi pur dianzi nomate, magnifica, humilde, e temperata (...)". Idem ibidem.

${ }^{111}$ Idem ibidem, pp. 349-361.

112 “(...) Ma se nella sola elettione, ò scelta delle parole, e nell' ornamento recato loro dalle figure, la elocutione consiste, ne stile può giustamente nomarsi, ne tutto il corpo del favellare verrà da lei nobilitato, come conviene (...). E' dunque necessario, per ridurre à perfetta formal' elocutione, che alle parole, \& alle figure alcuna cosa s' aggiunga; in virtù di cui meglio il pregio loro ne' cóponimenti si riconosca; cioè a dire, per parere dell' Alicarnasseo, una giudiciosa collocatione (...). L'elocutione anchorche nella sua essenza perfetta, rimane però senza i caratteri del dire, e senza le forme, ò sieno idee della favella, indeterminata, \& otiosa: segno ne sia, che quando con virtì, e con regole da noi in queste particelle assegnate, un buon componimento s' esaminasse (...)". Idem ibidem, pp. 352-353/361.

${ }^{113}$ Idem ibidem.

114 “(...) se le cose grandi fossero del carattere Maggiore, le picciole del Minore argomento, $e$ materia, niun luogo havrebbe l' amplificatione, che come diceva Isocrate, le basse innalza, e le magnifiche abbassa (...)". Idem ibidem, p. 380.

${ }^{115}$ Idem ibidem, pp. 383-399.

116 “(...) Io scrivo dell' arte historica, \& hoggi mai m' avvicino ad un importante dubbio dello stile più proportionato, che con la dottrina della presente digressione haverassi à decidere (...). Il carattere conveniente all' historia: perche non si tratando in essa per lo più, e secondo la convenevolezza, altro che materie magnifiche, e grandi, come sono gli affari de Principi, e delle Republiche; le guerre, le paci, le alterationi degli imperij, le mutationi de principati, e cose somiglianti; che del solo carattere magnifico fosse capace l' historia (...)". Idem ibidem, p. 384. ${ }^{117}$ Idem ibidem, pp. 399-407.

118 “(...) Da tutto ciò, che fin' hora s'è divisato, alcuni corolari, si traggono, co' quali terminerassi la presente digressione. Primo. Lo stile è una maniera particolare, \& individua di ragionare, ò di scrivere, nascente dal particolare ingegno di ciascuno componitore, nell' applicatione, $e$ nell uso de caratteri del favellare, Secondo. Paragonato il carattere con lo stile, questo si tiene dalla parte della natura, e dell' ingegno, quello riguarda l' arte, e lo studio. Et in conseguenza questo si multiplica, e si varia secondo il numero, e la qualità degli ingegni (...). Terzo. L' interrogar alcuno in che stile egli scriva è sciocchezza; perche non può in altro stile comporre, che nel suo proprio, dettatogli dall' ingegno; se non se in quanto con l'imitatione può studiarsi d'esprimer, con qualche somiglianza, lo stile altrui; onde accioche l'interrogatione non sia fuor di proposito, si dourà dire, in che carattere scriva; quando però dell' imitation non s' intenda. Quarto. Ben si può dir quello è stil di Tucidide, e di Sallustio, ma non già questo è carattere di Tucidide, e di Sallustio; perche il carattere è commune à tutti, e non proprio di Tucidide, ò di Sallustio, come è lo stile (...)". Idem ibidem, pp. 406-407.

${ }^{119}$ Idem ibidem, pp. 409-675. 
${ }^{120}$ Idem ibidem, pp. 410-434.

121 “(...) Dice dunque lo Strada, che l' amplificatione, e' l commovimento degli affetti, come virtù proprie dell' oratore, vogliono dall' historico in tutto suggirsi: ed' io non so quando vera sia questa regola, quando generalmente, e senza niuna eccetione s' intenta. La amplificatione per vero dire, e' l commovimento delle passioni sono due de' più principali, \& efficaci strumenti, c' habbia l' arte oratoria fra' suoi arredi (...)". Idem ibidem, pp. 413-414.

${ }^{122}$ Idem ibidem, pp. 412-413.

123 “(...) Chi di costoro meglio s' apponesse, e di chi fosse la risolution più lodevole, io non intendo decire: so ben che Tullio esser ufficio del perfetto oratore il componer l' historia c' insegna; e ciò doveva accender l' animo à Plinio: sò che Quintiliano dell' historia parlando dice est enim proxima poetis, e quadam modo carmen solutum; e questo mosse Agatia. Congiunta poi all' uno, \& all' altro scrittore l' autorità de maestri maggiori dell' arte, $m$ ' hà fatto risolvere à soltimente cercare la communanza, e la differenza c' hanno la poesia, e l' orationi, con l' historia; perche da questa mia fatica si trarrà certo il sentimento dell' uno, $e$ dell'altro; e quel che più rileva, il modo di regolatamente ordinare, non solamente l'elocutione, o il carattere; ma le parti anche maggiori di tutto il corpo dell' historia, che la forma più tosto, che la materia riguardano (...)". Idem ibidem.

124 “.... All' incontro l' historico studiandosi, secondo la sua obligatione, di rappresentar per l' appunto, ma vivamente le materie, che narra, procura che nell' animo de' leggenti s' imprimano quali sono: onde il suo primo fine è d' esprimer la verità degli accidenti, e d'adeguargli con le parole; i quali perche secondo la diversita delle lor circostanze, quando efficacemente si narrino, destano in chi legge diversi affetti, non ripugna al candore, \& alla veracità dell' historico, che in caso tale sieno commossi gli animi da suoi racconti; porque che ciò viene ad essere effetto della materia narrata; ne per sua colpa rimane in parte alcuna offesa la verità. e (cic) questo discorso all' amplificatione applicar parimente si dee: perche quella nell' oratore altera il fatto, nell' historico lo rappresenta: ivi innalza le cose picciole, \& abbassa, le grandi con la facondia, qui l' une, e l'altre puntualmente descrive, \& uguaglia con le parole; onde se nella scuola dell' eloquenza essaggeratione s' appella, nel consiglio dell' historia ponderatione si chiamerà (...)". Idem ibidem, pp. 418-419.

125 “(...) Ma prima d'avanzarmi più oltre nella materia è necessario, ch' io rivolga la penna al buon componitor dell' historia, e dell' importanza della sua carica l' ammonisca. Se parte alcuna di così nobile mestiere vuol esser maneggiata con giudicio, e con arte, la testura delle dicerie singolar diligenza richiede (...)”. Idem ibidem, p. 437.

${ }^{126}$ Idem ibidem, p. 447.

${ }^{127}$ Idem ibidem, p. 455.

128 “(...) non lodar solamente, e vituperare può lo scrittor dell' historia, ma per obligo dell' ufficio à lodare, \& à vituperare è strettamente tenuto (...)". Idem ibidem, p 470.

129 “(...) Colora (...) à compor l' historie s' accingono; cioè che il buon historico, se brama di sostener le sue parti come conviene, dee perfettamente saper la Retorica, per conoscer bene $i$ generi l' uno separato dall' altro, e poi come l' uno all' altro si riduea; la fede degli argomenti proportionata a ciascuno, gli stati delle quistioni; il modo di maneggiar gli entendimemi per

TOPOI, v. 7, n. 13, jul.-dez. 2006, pp. 331-378. 
acquistar la credenza degli uditori; la maniera d' amplificar le sue ragioni, e di diminuir quelle degli avversari (...)". Idem ibidem, p. 448.

130 “(...) L' usanza di lodar dopo morte gli huomini valorosi con publiche orationi ne funerali, non è si gloriosa per color, che son morti, che non sia più giovevole per gli altri, che rimangano in vita. Impercioche le forde ceneri di quegli incliti Eroi non han prurito di vanità, che renda loro disiderabili le lusinghe; ma la debolezza de posteri hà ben necessità d' insegnamenti, e d' esempio, che l'avvalorino nel camino della virtù (...)". Idem ibidem, p. 466.

131 “(...) Il dottissimo Pontano nel dialogo appellato da Attio Sincero, in cui, della poesia insieme, e dell' historia si divisa, par ad alcun moderno, che l' ufficio dell' oratore all' historico si fattamente accommuni, che fra l' uno, el'altro mestiere non si riconosca divario (..)". Idem ibidem, p. 469.

${ }^{132}$ Idem ibidem, pp. 488-503; 504-517.

${ }^{133}$ Idem ibidem, pp. 488-517.

${ }^{134}$ Cf. CASTELVETRO, Lodovico. Poetica d'Aristotele vulgarizzata et sposta. Basiléia, 1576 .

135 “(...) Prima Propositione del Castelvetro. Non si può haver perfetta, e convenvole notitia della poesia per arte poetica, se prima non s' hà notitia compiuta dell' arte historica. Provasi da lui la proporsione; perche prima di natura è la verità, e la cosa rappresentata, che la verisimiltudine, e la cosa rappresentante; essendo che queste da quelle dipendono (...). Seconda Propositione. 'Historia è narratione secondo la verità d'attioni humane memorevoli avvenute; e poesia è narratione secondo la verisimiltudine d' attioni humane possibili ad avvenire,' dunque prima l' historia dobbiam conoscere, e poscia la poesia. Terza Propositione. L' historia è cosa rappresentata, e la poesia è cosa rappresentante; dunque la cognitione dell' historia dee precedere alla cognitione della poesia. Quarta Propositione. Gli ammaestramenti per ben comporre un' historia non sono per la maggior parte propri dell' historia, ma communi all' historia, \& alla poesia: dunque prescritta l' arte historica riman soverchia l' arte poetica. Presuppone finalmente il Castelvetro, che l'arte dell' historia non sia stata composta, e dalla via tenuta da Luciano, dal Trapezuntio, e da Ridolfo Agricola in volerla comporre, si persuade di provar la verità della dottrina, da noi nelle quatro propositioni raccolta (...)". Op. cit., pp.489-490.

136 “(...) La verità è prima di natura della somiglianza del vero: Ma l' historia è narratione secondo la verità, e la poesia secondo la somiglianza del vero: Dunque l' historia è prima di natura della poesia. Il sillogismo è di quattro termini, perche la verità nella maggior proportione, è verità metafisica, universale, \& astratta; nella minore è morale, particolare, e concreta; perchel' historia non narra generalmente la verità, ma le attioni humane particolari, che vere sono (...)". Idem ibidem, p. 492.

137 “(...) Due sorti d' ordine (...) si distinguono. Uno appellano naturale; l' altro artificiale (...). Il primo segue la serie ò della natura, ò del tempo; in tanto che facendosi nel racconto delle cose da capo, senza pertubatione delle parti, al mezo, \& al fine sucessivamente perviene (...). Idem ibidem, p. 496. 
138 “(...) Dato che ne’ poemi s' ammetta l'ordine pertturbato, non è si proprio della poesia, che non l'adoprino per suo parimente l'oratore, e l' historico, secondo l'occasioni (...)". Idem ibidem, p. 515.

${ }^{139}$ Idem ibidem, pp. 518-548.

${ }^{140}$ Idem ibidem, pp. 518-533.

${ }^{141}$ Idem ibidem, p. 520.

142 “(...) l'Alicarnasseo, (...), dice; che gli historici buoni all' ordine ò de tempi, ò de luoghi s' appigliano (...) Pógo per hora da un lato le Cronache, le Effemeridi; e le Vite; poiche il nome loro solamente udito da chi nõ è un bronco, dichiara come in esser altr' ordine non si serba, fuorche quello del tempo (...) Degli Annali si può dire il medesimo: poiche prendendo il nome dagli anni, dagli anni ancora è forza, che vengano regolati (...). La testura degli Annali à quell' antica seccaggine, ricordata da Tullio (...)". Idem ibidem, pp. 520-521.

143 Idem ibidem, p. 548-569.

144 “(...) Se dunque la dicitura historiale è somigliante alla sofistica; e questa sorte alla poetica si rassomiglia, per la regola matematica, 'qua sunt eadem uni tertio eadem inter se', necessariamente conchiudesi, l' elocutione dell' historia esser vicina favella della poesia. Questa medesima illatione si trae da chi discorre co' principij posti da Ermogene: il quale dividendo quel ch' egli noma politico genere di favelare, ne' tre notissimi membri giudiciale, deliberativo, e dimonstrativo; l' ultimo con proprio nome appella panegirico, e poi più particolarmente Platonico, perche sopra tutti gli scrittori singolarmente eccellenti su Platone in quella sorte di ragionare; come il medesimo Ermogenes afferma. A questo sottordine non solamente la poesia, ma insieme l' historia; come di quella dilicatura d' ornamenti (...)". Idem ibidem, pp. 553-554.

${ }^{145}$ Idem ibidem, p. 570-595.

146 “(...) L' historico poscia à cui è proposto l' utile de leggenti (...) usa le descrittion sempre che (...) necessarie (...) per maggior chiarezza de suoi racconti (...)”. Idem ibidem, p. 572.

147 “(...) L' historico poscia à cui è proposto l' utile de' leggenti, agevolato però, e reso più amabile dal diletto, che l' accompagna, usa le descrittioni sempre che ò necessarie, ò giovevoli appaiono, per maggior chiarezza de' suoi racconti (...)”. Idem ibidem, p. 575.

148 “(...) come insegna Aristotele; e suol di tutto punto fabricarsi le descrittioni à suo modo, adornandole di quegli accidenti, che render la possono in tempo medesimo più maravigliosa, e credibile (...). Sia dunque la seconda regola dell' historico; Nelle descrittioni non dee per allettamento di vaghezza allontanarsi dal vero, nelle parti almeno sostantiali, \& importanti (...)". Idem ibidem, p.576-577.

149 “(...) Vaglia di terza regola l' intender interamente bene la materia intorno à cui la descrittione s' avvolge (...)”. Idem ibidem, p. 577.

150 “(...) Tanto che per non errare (...) dallo scrittore intender puntualmente, ciò che descrive (...)”. Idem ibidem, p. 579.

151 “(...) E Eerò vero (e sia la quinta regola) ch' avvenendo si lo scrittore in materia lontana dal vulgo, e che tutto di sotto gli occhi della moltitudine non può cadere d' esser minuto à bastanza 
in descriverle; perche in caso tale, egli è maestro, che semplicemente non narra, ma insegna a' leggenti (...)". Idem ibidem, p. 583.

${ }^{152}$ Idem ibidem, pp. 595-569.

${ }^{153}$ Idem ibidem, pp. 595-603.

154 “(...) come afferma (...) Ermogene: ben si vede, che il carrattere conveniente all' historia sarà quel, che risulta dall' accozzamento delle forme indirizzate alla grandezza del dire, e da noi Maggiore viene appellato (...). Comprese ciò benissimo Ermogene, il qual volendo, che il carattere panegirico, cioè à dire quel ch' adopra l' historico (...)". Idem ibidem, pp. 597/602. ${ }^{155}$ Idem ibidem, pp. 604-614.

156 “(...) Ma non debbo in questo luogo prender la difesa dell’ eloquenza tradita (...). Di proposito gli studi dell' eloquenza coltivano, ed' io vengo più da vicino à cercar qual sia la dicitura conveniente all' historia (...). Tullio ripone la dicitura historiale in un termine, che nè s' accosti alle strettezze del parlar dialettico, ne cerchi l' acrimonia, e la vehemenza dell' oratorio; ma soavemente copiosa, unisca all' abbondaza, per cui dal dialetico s' allontana, la piacevolezza, ò vogliam dirla con parola più latina, ma più significante, la lenità, che la disgiugne dall' asprezza, e dalla vehemenza dell' oratore (...)". Idem ibidem, pp. 606/608.

${ }^{157}$ Idem ibidem, pp. 615-623.

${ }^{158}$ Idem ibidem, pp. 624-645.

${ }^{159}$ Idem ibidem, p. 646-676.

${ }^{160}$ Tomo o termo 'gráfica' no sentido grego graphein que significa tanto escrever quanto pintar, por homologia e não por identidade propriamente dita ou igualdade positiva.

${ }^{161}$ Aqui, ressalto três coisas: primeiro que penso o conceito "farmácia" como remédio, como phármakon do sofista que as práticas seiscentistas imitam e moralizam e que pode ser veneno, dependendo do uso e função que assume. Nesse sentido, as tópicas da invenção do gênero histórico funcionariam como repertório de remédios teológico-políticos, elenco de conselhos administrativos, aplicados aos males do corpo monárquico católico nas questôes públicas de que a história também se ocupa. Segundo, entendo o termo "topografia" como a disposição dos registros descritivos dos lugares inventados na farmácia, sejam os lugares de pessoa, sejam os de cidade etc. Assim, entendo a dispositio do gênero histórico como topográfica. Terceiro, como cosmética, penso a elocução mimética do gênero, suas relações de ilusão, de aparências, cujas substâncias são cosméticas e não positivamente reais ou necessariamente empíricas. Doutrinado pela arte, o gênero histórico produz a ilusão do real por meio dos ornatos discursivos.

${ }^{162}$ Cf. O Juízo - Discurso Acadêmico. Trad. João Adolfo Hansen. In: NASCIMENTO, Evando et OLIVEIRA, Maria Clara Castellóes de. (Orgs.). Literatura e filosofia: diálogos. v. 1. Juiz de Fora/São Paulo, 2004, p. 169. 


\section{RESUMO}

O ensaio apresenta, na primeira parte, o Dell'Arte Historica (1636) de Agostino Mascardi e seu ambiente letrado; traduz e comenta, na segunda parte, as passagens mais relevantes da preceptiva, a fim de estabelecer uma descrição de sua doutrina que permita definir, na terceira parte, os modos ibérico-italianos de escrita seiscentista da história em seus diferentes subgêneros. Pensa-se contribuir, assim, não só com a recepção do importantíssimo, mas quase desconhecido no Brasil, Dell'Arte Historica, como também contribuir para os estudos de gênero histórico do século XVII. Palavras-chave: teologia-política; retórica; história; gênero histórico; Dell'Arte Historica; Agostino Mascardi.

\section{ABSTRACT}

The essay presents, in the first part, the Dell'Arte Historica (1636) by Agostino Mascardi and its lettered environment; it translates and comments, in the second part, the most considerable passages from perceptive, in order to establish a description of its doctrine that allows to define, in the third part, the Iberian-Italian ways of the sixteen hundred written of the History in different subdivisions. It's thought to contribute, this way, not only with the reception of the important Dell'Arte Histories by Agostino Mascardi, wich is almost unknown in Brazil, but also to the studies of the historical divisions of the XVII century.

Key-words: political-theology; rethoric; history; historical genre; Dell' Arte Historica; Agostino Mascardi 